\title{
Criminal Recidivism after Prison and Electronic Monitoring
}

\section{Citation}

Di Tella, Rafael, and Ernesto Schargrodsky. "Criminal Recidivism after Prison and Electronic Monitoring." Journal of Political Economy 121, no. 1 (February 2013): 28-73.

\section{Published Version}

http://www.journals.uchicago.edu/doi/full/10.1086/669786

\section{Permanent link}

http://nrs.harvard.edu/urn-3:HUL.InstRepos:28548029

\section{Terms of Use}

This article was downloaded from Harvard University's DASH repository, and is made available under the terms and conditions applicable to Other Posted Material, as set forth at http:// nrs.harvard.edu/urn-3:HUL.InstRepos:dash.current.terms-of-use\#LAA

\section{Share Your Story}

The Harvard community has made this article openly available.

Please share how this access benefits you. Submit a story. 


\title{
Criminal Recidivism after Prison and Electronic Monitoring
}

\section{Rafael Di Tella}

Harvard University, Canadian Institute for Advanced Research, and National Bureau of Economic Research

\section{Ernesto Schargrodsky}

Universidad Torcuato Di Tella

\begin{abstract}
We study criminal recidivism in Argentina by focusing on the rearrest rates of two groups: individuals released from prison and individuals released from electronic monitoring. Detainees are randomly assigned to judges, and ideological differences across judges translate into large differences in the allocation of electronic monitoring to an otherwise similar population. Using these peculiarities of the Argentine setting, we argue that there is a large, negative causal effect on criminal recidivism of treating individuals with electronic monitoring relative to prison.
\end{abstract}

\section{Introduction}

Every year a large number of individuals are sent to prison. Given that prisons are expensive to build and run and often involve cruel treatment of fellow citizens, possibly contributing to the conversion of inmates into

We thank the editor (Derek Neal), a referee, David Abrams, Roland Benabou, Ilyana Kuziemko, Randi Hjalmarsson, Néstor Gandelman, Julio Rotemberg, Justin Wolfers, and participants at several workshops and the 2007 conference "Crime, Institutions and Policies" co-organized by the National Bureau of Economic Research and the Laboratorio de Investigaciones sobre Crimen, Instituciones y Políticas at the Universidad Torcuato Di Tella for many helpful suggestions; and to Juan Marcos Wlasiuk, Cecilia de Mendoza, David Lenis, Héctor Gatamora, and Ramiro Gálvez for excellent research assistance. We thank the Canadian Institute for Advanced Research, the World Bank, and London Derby for financial

[Journal of Political Economy, 2013, vol. 121, no. 1]

(c) 2013 by The University of Chicago. All rights reserved. 0022-3808/2013/12101-0003\$10.00 
"hardened" criminals, it is unsurprising that alternatives to imprisonment have been tried out. One of the more intriguing experiments in this area is the substitution of electronic monitoring for incarceration. ${ }^{1}$ "Electronic tagging," as it is also sometimes called, involves fitting offenders with an electronic device (on the ankle or wrist) that can be monitored remotely by employees of a correctional facility who can verify whether the individual is violating a set of preestablished conditions. One that is common is a request to stay at home, although in many cases a provision for attending work or school is included. Technological progress has fostered the use of these devices, making them cheaper and safer (e.g., recent versions can include global positioning [GPS] and voice recognition technology). By 2010, more than 500,000 people in the United States and Europe alone had been "treated" with electronic monitoring, in spite of the obvious complexity of a full cost-benefit analysis. In this paper we seek to contribute to an evaluation of electronic monitoring by providing evidence on one of the estimates needed for such an exercise: the difference between the recidivism rate of offenders treated with electronic monitoring and the recidivism rate of offenders released from a standard prison.

Theoretically, the difference in these two recidivism rates is ambiguous. On the one hand, specific deterrence theory suggests that spending time under electronic monitoring rather than incarceration might make low punishment salient, implying a positive relationship between light punishment (electronic monitoring) and recidivism. On the other hand, several theories point to a negative relationship. For example, imprisonment might be criminogenic through harsh prison conditions or peer effects that are not present under electronic monitoring. In particular, electronic monitoring could prevent contact with hardened criminals or reduce the perception that society is "mean" and "deserving of the crime it receives" (one variation is in Sherman and Strang [2007]). Moreover, electronic monitoring could differ from prison in its effect on the offender's labor market prospects or social integration (perhaps through stigmatization or through an effect on the accumulation of skills). ${ }^{2}$

support. We are extremely grateful to Marcelo Lapargo and Santiago Quian Zavalia, as well as Rodrigo Borda, Ricardo Costa, Fernando Díaz, Julio Quintana, Sergio Buffa, Martín Canepa, José Castillos, and Marcelo Acosta for generous conversations that improved our understanding of the legal system and the electronic monitoring program.

${ }^{1}$ See, e.g., the discussions in Schwitzgebel (1969), Petersilia (1987), Schmidt and Curtis (1987), Morris and Tonry (1990), Payne and Gainey (1998), Tonry (1998), and Renzema and Mayo-Wilson (2005).

${ }^{2}$ Reviewing the vast literature on these issues is beyond the scope of this paper. But many relevant aspects are covered in the recent review by Bushway and Paternoster (2009). See also Nagin (1998) on the evidence on deterrence, as well as Sherman and Berk (1984), Smith and Gartin (1989), Stafford and Warr (1993), and Piquero and Pogarsky (2002) for discussions of different aspects of deterrence. On peer effects, see, e.g., Glaeser, Sacerdote, 
A simple comparison of recidivism rates across the prison and electronic monitoring samples, however, is typically not very informative. At least two practical empirical problems appear when attempting to estimate a causal estimate, one of which can be called a problem of selection and the second a problem of differential risk of the target population. The problem of selection refers to the fact that at least one potential criterion for the granting of electronic monitoring to an offender is her or his risk of recidivism. Thus, low postrelease recidivism of a group of offenders treated with electronic monitoring could simply reflect the success of the legal system at the selection stage if the objective was to target "kind" types (i.e., the group of low-risk offenders within the population). The problem of "differential risk of the target population" refers to the possibility that electronic monitoring programs are restricted to low-risk populations (e.g., those whose most serious crime is drunk driving). The failure to detect a negative effect of electronic monitoring on recidivism could simply reflect that this population is already at very low risk of crime (and the control population receives a very light punishment). In practice, these and other problems have interfered with the evaluation of electronic monitoring. In a recent review by Renzema and Mayo-Wilson $(2005,215)$ the authors conclude that "applications of electronic monitoring as a tool for reducing crime are not supported by existing data." A similar conclusion is reached in the review by Aos, Miller, and Drake $(2006,11)$, who "find that the average electronic monitoring program does not have a statistically significant effect on recidivism rates."

In this paper we study electronic monitoring in the Province of Buenos Aires, Argentina. We measure recidivism through rearrest rates of offenders treated with electronic monitoring since the program's inception in the late 1990s. As a benchmark, we take a sample of former prisoners of similar observable characteristics treated with incarceration. We find a large, negative, and significant correlation between electronic monitoring and rearrest rates.

Two features of the institutional setting we study suggest that a reasonable interpretation of our estimate is that it is the causal effect of treating an apprehended offender with electronic monitoring instead of prison. The first feature is that offenders are randomly matched to judges, and the second is that the likelihood an offender is sent to electronic monitoring instead of prison differs substantially across judges. This second feature occurs, in part, because of the usual ideological differences across judges (see, e.g., Waldfogel 1991) and in part because

and Scheinkman (1996) and Bayer, Hjalmarsson, and Pozen (2009). An early reference on the correlation between cognitive skills and imprisonment is Banister et al. (1973). Stigmatization following incarceration (by the self or others) is discussed, e.g., in Schwartz and Skolnick (1962). 
these ideological differences become exaggerated in Argentina. One likely reason for this exaggeration is disagreement about the proper status of detainees: the vast majority of people in Argentine prisons were caught in the act (so there is an informal presumption of guilt) but, given the slow workings of the legal system, are still on pretrial detention and hence are presumed innocent (i.e., they are alleged offenders who have not received a final sentence in a full trial). ${ }^{3}$ Besides this conflicting institutional setting, the intervening judges are not passing sentences in lengthy trials but rather making a decision about the conditions for supervision until final sentence. This involves a minimum of information gathering, so there is ample room for a judge's ideological predisposition to play a role. Additionally, Argentine jails and prisons have frequently been denounced as excessively cruel by human rights organizations (see, e.g., Centro de Estudios Legales y Sociales 2011). This results in two stereotypes: judges who frequently allocate electronic monitoring (which the media often label garantistas, from their emphasis on "individual guarantees"; in the United States, this would approximately correspond to liberal) and judges who never do so (these are often called mano dura, literally "tough hand"; in the United States, this would approximately correspond to conservative). Since the assignment of judges is exogenous to prisoners' characteristics (whenever a person is detained by the police, she or he is assigned to the judge who was on duty on that day, and duty turns are assigned by a lottery), it is possible to instrument the decision to send an offender to prison or electronic monitoring with a proxy for the judge's ideology. The instrumental variable results reveal a robust, negative, and significant effect of electronic monitoring on later rearrest rates of between 11 and 16 percentage points, or approximately half the baseline recidivism rate.

The institutional features of the Argentine setting also ensure that electronic monitoring is applied to offenders who have committed relatively serious crimes, thus addressing the problem of differentially low risk of the target population. Note also that electronic monitoring in Argentina is associated with the objective of lessening the cost of the pretrial period. In other words, the counterfactual for the group under electronic monitoring is imprisonment. This contrasts with the phenomenon

\footnotetext{
${ }^{3}$ On the extensive use of pretrial detention in Latin America and for some comparative data, see Schonteich (2008). The widespread use of pretrial detention is due to both the extremely slow workings of the legal system and specific legal institutions in Argentina. One example is the fact that the transition from detained before trial to "sentenced" takes place only when the appeals process has been exhausted. In contrast, in several commonlaw countries including the United States, individuals are on pretrial detention only until their first trial. Thereafter, they are imprisoned, even if they are appealing the first sentence. Strictly speaking, the United States has pretrial detention whereas in Argentina it should be called detention prior to final sentence (although, as most detainees in our sample are waiting for their first trial, we use the term "pretrial" detention).
} 
of "net widening" in the United States, whereby electronic monitoring is linked to an increased punitiveness of the penal system, as it is often applied to former prisoners who would otherwise have been on lower supervision (e.g., parole supervision). Finally, it is worth emphasizing that in Argentina, electronic monitoring does not complement other programs (education, work, anger management, drug addiction, alcohol abuse, etc.), something that facilitates the interpretation of our treatment. ${ }^{4}$

Previous work on electronic monitoring using data from the United States has been inconclusive. For example, Courtright, Berg, and Mutchnick (1997) compare recidivism for drunk driving offenders treated with electronic monitoring versus those receiving jail sentences. The recidivism rates following release were extremely low for both groups (and the difference was not significant). The paper by Gainey, Payne, and O'Toole (2000) finds some evidence of lower recidivism among (mostly low-risk) offenders who spend time under electronic monitoring, but the effect is not robust to the inclusion of control variables. Previous work has found it hard to control for the possibility that offenders treated with prison might be particularly dangerous and inherently more likely to commit crimes. ${ }^{5}$ Renzema and Mayo-Wilson (2005) review the literature and find only two studies with random assignment and with recidivism as the dependent variable, including Petersilia and Turner (1990). Unfortunately, they describe several limitations in these studies (including incomplete administration of the program) and conclude that they do not help in the evaluation of electronic monitoring. ${ }^{6}$ An interesting paper is Marklund and Holmberg (2009), which evaluates a Swedish program that allows prisoners to apply to electronic monitoring as a substitute for prison (early release) as long as they have an occupation and they subject themselves to regular sobriety controls. ${ }^{7}$ They find that partici-

\footnotetext{
${ }^{4}$ The evidence available from the United States and Europe typically refers to concomitant programs, where electronic monitoring is only one of the treatments. Renzema and Mayo-Wilson (2005) discuss studies on groups judged to have intermediate/high risk of recidivism, which are still on the low side when compared to the groups we study.

${ }^{5}$ Interestingly, papers that look at rearrest rates of people with different lengths of time on electronic monitoring (but who are all treated) suffer less from this criticism (see Gainey et al. 2000).

${ }^{6}$ It is worth pointing out that the sign of the bias introduced by selection problems depends on the nature of the program. For example, Finn and Muirhead-Steves (2002) describe the application of electronic monitoring to violent offenders who would otherwise have been released in the state of Georgia. It is compared with a group of violent offenders who were released and finds no difference in recidivism rates. Given that this is a case of net widening, selection bias has the opposite sign: those selected for continued supervision are at a higher risk of recidivism, so the similarity in recidivism rates is consistent with socially positive effects of electronic monitoring.

7 The average age of the electronic monitoring group in that program was 38 . In comparison to the prison population sentenced to a similar term in prison, the group of successful applicants to the electronic monitoring program contained a smaller proportion of individuals with prior convictions and who had used drugs in prison.
} 
pation in the electronic monitoring program is associated with lower recidivism.

Our paper is also related to work studying the effect of imprisonment on recidivism, where a similar selection problem is present (see, e.g., Villettaz, Killias, and Zoder 2006; Lerman 2009). Two comprehensive reviews by Gendreau, Goggin, and Cullen (1999) and Nagin, Gullen, and Jonson (2009) conclude that incarceration appears to have a null or mildly criminogenic effect on future criminal behavior but that the evidence is not sufficiently strong to be used in policy. ${ }^{8}$ Two recent papers by Chen and Shapiro (2007) and Kuziemko (2013) pay special attention to selection and reach somewhat opposite conclusions. Chen and Shapiro (2007) exploit the fact that there is a discontinuity in the mechanism that assigns prisoners to security levels (and hence prison conditions) in the United States. Thus, they are able to observe recidivism rates of former prisoners that were ex ante very similar (i.e., on both "sides" of the cutoffs) and conclude that, if anything, harsher prison conditions lead to slightly higher recidivism rates (see also Camp and Gaes 2009). On the other hand, Kuziemko (2013) finds that recidivism falls with time served using two different identification strategies. In one, she exploits "an over-crowding crisis" that resulted in the release of 900 prisoners on a single day, so that conditional on the original sentence, the length of time served for this group was determined by the date the sentence began. The second is a regression-discontinuity design using the variation in time served generated by cutoffs in parole board guidelines. Drago, Galbiati, and Vertova (2011) also study the relationship between prison conditions and recidivism and do not find that harsher conditions reduce postrelease criminal activity (see also Song and Lieb 1993; Needels 1996; Katz, Levitt, and Shustorovich 2003; Helland and Tabarrok 2007; Bhati and Piquero 2008). It is also worth mentioning that our identification strategy, based on random assignment to judges with different ideological inclination, is not new. For example, it is very much related to the one employed by Kling (2006) in his study of the effects of incarceration length on employment and earnings. ${ }^{9}$

\footnotetext{
${ }^{8}$ Nagin et al. $(2009,115)$ explain, "Remarkably little is known about the effects of imprisonment on reoffending. The existing research is limited in size, in quality, in its insights into why a prison term might be criminogenic or preventative, and in its capacity to explain why imprisonment might have differential effects depending on offenders' personal and social characteristics. Compared with noncustodial sanctions, incarceration appears to have a null or mildly criminogenic effect on future criminal behavior. This conclusion is not sufficiently firm to guide policy generally, though it casts doubt on claims that imprisonment has strong specific deterrent effects."

${ }^{9}$ Interestingly, he finds no consistent effect using instrumental variables for incarceration length based on randomly assigned judges with different sentencing propensities. On interjudge variation in sentencing, see also Waldfogel (1991), Payne (1997), and Anderson, Kling, and Stith (1999). Using this strategy, Green and Winik (2010) find similar recidivism rates after incarceration and probation, while a recent paper by Aizer and Doyle (2011)
} 
The paper is structured as follows. Section II describes the implementation of electronic surveillance in the Province of Buenos Aires. Section III describes our data and empirical strategy. Section IV presents our main set of results, and Section $\mathrm{V}$ provides a welfare discussion that includes the problem of escapees. Section VI presents conclusions.

\section{Judges, Prisons, and the Use of Electronic Monitoring in Argentina}

In this section we discuss three important elements of the institutional and theoretical background suggesting that it is possible to use an instrumental variables strategy. In the first subsection we describe the legal process that individuals must follow, from the time they are arrested until they reach trial, with special attention to the role of the judge. In the second subsection we describe anecdotal evidence suggesting very large ideological differences across judges (this issue is formally revisited in Sec. III after we introduce the data). Finally, in the last subsection we present a brief model with several of the features of the Argentine setting and where ideological judges determine electronic monitoring (EM) allocation.

As background, it is worth noting that crime in Latin America is a major social and economic problem. Deaths due to violence around the year 2000 were 200 percent higher than in North America, 450 percent higher than in Western Europe, and 30 percent higher than in the former Communist bloc (Soares and Naritomi 2010). Our data come from Argentina, a country with traditionally low levels of crime, which has conformed to the Latin American patterns of high crime rates during the 1990s. Within Argentina, our focus is Buenos Aires, the largest and economically most significant province, with a population of almost 15 million people (about 38 percent of the population of the country). This province was the first place in Latin America where an EM program was implemented.

\section{A. The Process: How Alleged Offenders End Up in Prison or EM}

By 2007, the Penitentiary Service of the Province of Buenos Aires hosted a population of approximately 26,990 inmates, which represented 44.5 percent of the total population under penal supervision of the whole country. ${ }^{10}$ The conditions of confinement are extremely poor, perhaps be-

uncovers large increases in the likelihood of adult incarceration for those incarcerated as juveniles. In a similar spirit, Doyle (2008) uses the randomization of families to child protection investigators to estimate causal effects of foster care on adult crime.

${ }^{10}$ Data in this section are compiled from several sources in the reports by the Asociación por los Derechos Civiles (2006) and Unidos por la Justicia (2009). The imprisonment rate of the Province of Buenos Aires in 2007 (188 per 100,000 population) is higher than the country's rate (156). As a reference, consider that this rate is 758 for the United States, 282 
cause the inmate population held in prisons and jails experienced a large increase (from 12,223 in 1994 to a peak of 30,721 in 2005) without a corresponding increase in infrastructure investment. By the end of our sample period in 2007, the overpopulation of the Buenos Aires penal system is estimated to be well in excess of 30 percent, with most of the inmates lodged in prisons (almost 88 percent, and only 12 percent lodged in jails). For the purposes of this paper, we focus on three institutions of the provincial penal system: jails, prisons, and the EM program.

Jails are local facilities run by the provincial police force in close connection with the legal institutions of the judicial district (in particular, the judges and prosecutors deciding on the alleged offenders, which are the focus of this paper). Given that they are typically part of a police station, the ratio of officials to detainees is relatively high. This means that, even though the conditions of detention are extremely poor, they can be less chaotic than in some prisons. Another important feature is that, typically, detainees in local jails are relatively close to their families. Prisons, on the other hand, are run by the province's Penitentiary Service. With relatively few (46) prisons in the province, alleged offenders lodged in them are often far from their relatives. Several international organizations gathered evidence of overcrowding and lack of food and hygiene in both jails and prisons, which included at least one documented example of detention in a container with neither ventilation nor sanitation services. Figure 1 provides a picture. This led to several episodes of violence and rioting, particularly in the prisons of the Province of Buenos Aires in the 1990s. An official report concludes that "prisons are schools of criminals where detainees study bad arts and graduate with more violence and social resentment."11

The third correctional institution is the EM program. ${ }^{12}$ In late 1997, the Province of Buenos Aires pioneered in Latin America the use of EM

for Chile, 220 for Brazil, 197 for Mexico, 215 for Uruguay, 114 for Canada, 97 for France, and 92 for Germany. Isla and Miguez (2003) provide an account of urban violence in Argentina using ethnographic evidence from low-income areas, prisons, and gangs.

${ }^{11}$ See "The Prison, School of Criminals," La Nación, August 15, 2010. In one well-known episode, the leaders of a mutiny cooked several rival prisoners in the prison bakery and fed them to the prison guards. The media have covered these episodes as well as the spread of HIV/AIDS and its use as a weapon through in-prison rape (e.g., "Mutinies and Death in Prison," La Nación, April 3, 1996). On the quality of life in jails and prisons in the Province of Buenos Aires, see Borda and Pol (2007) and Alzua, Rodriguez, and Villa (2010). One apparent problem is a remarkably low staff/prisoner ratio (see Isla and Miguez 2003; Unidos por la Justicia 2009).

12 Gomme (1995) explains that a Harvard psychologist, Robert Schwitzgebel, developed the first EM device as a humane and inexpensive alternative to custody. In 1977, Judge Jack Love of Albuquerque, NM, was inspired by an episode in the Spiderman comic book series. Apparently Spiderman had been tagged with a device that allowed a villain to track his every move. Judge Love persuaded an electronics expert, Michael Goss, to design and manufacture a monitoring device, and in 1983, Love sentenced the first offender to house arrest with EM. 


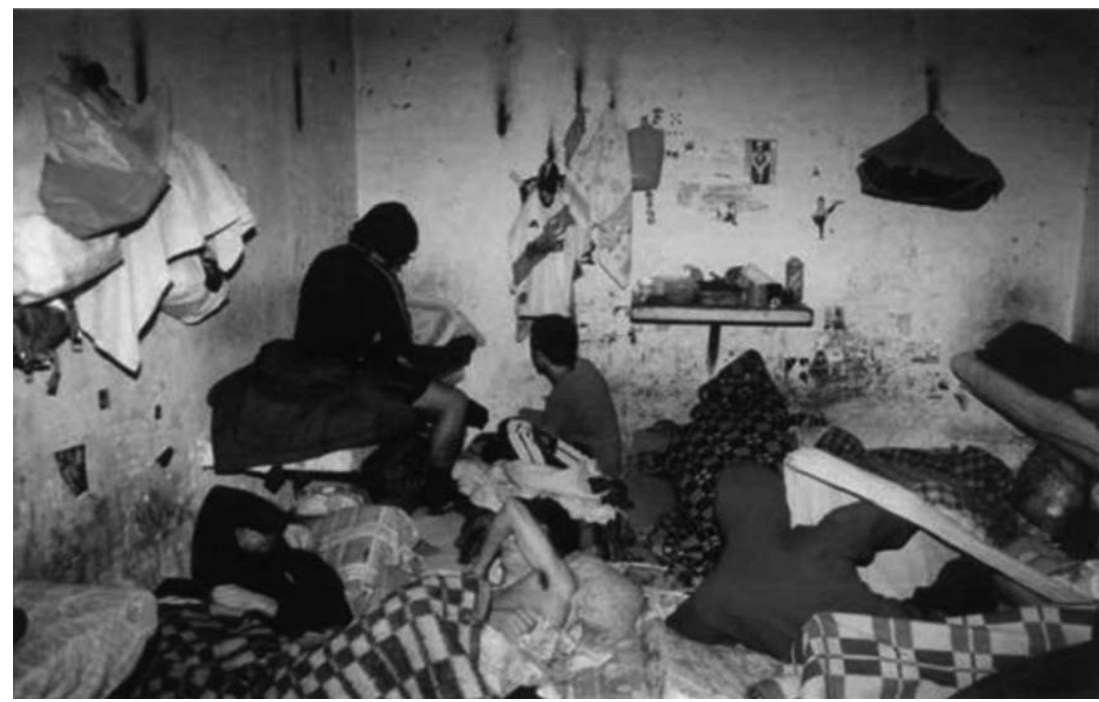

Fig. 1.-Conditions of confinement in the Province of Buenos Aires. Source: http:// procesalpenal.wordpress.com.

for the custody of inmates. ${ }^{13}$ Under the program, offenders stay at home wearing a bracelet on their ankle. The bracelet transmits a signal to a receptor installed in the offender's house. If the signal is interrupted, manipulation is detected, or vital signs of the individual are not received, the receptor sends a signal to the service provider through a telephone line. The private provider investigates the reason for the signal and, whenever necessary, reports to the EM office of the Buenos Aires Penitentiary Service, which sends a patrol unit to the inmate's house. The contractor is the South American representative of a leading international provider. The fee paid by the provincial government in May 2007 was AR $\$ 32$ per day (equivalent to approximately $\$ 10$ in May 2007).

The EM program was relatively small, with a capacity of handling a maximum of 300 detainees simultaneously. It was run by a specialized division within the province's Penitentiary Service, employing fewer than 20 individuals. This office received the formal requests from the judges and allocated the bracelets on a first-come, first-served basis. At its inception, EM was granted to the old and terminally ill, with the objective of allowing them to spend their final days with their families and under house arrest. Buenos Aires legislation also allows the use of EM as a way to improve the conditions under which individuals await trial. Eventually, all new entries to the EM program were individuals on pretrial de-

${ }^{13}$ A GPS monitoring system was implemented in Bogotá, Colombia, in 2009, while the Peruvian Congress approved the use of EM in 2010. As of 2012, proposals are under consideration in Brazil, Chile, and Uruguay. 
tention. Thus, the coverage shifted over time toward individuals under criminal indictment awaiting final sentence (the average age in our sample is 25.7; standard deviation 5.7). In practice, there were few restrictions on its allocation, so individuals accused of any crime, even rape or murder, or with a criminal history qualified for the use of EM (table 1 illustrates). Given the very slow functioning of the legal system, the period of detention prior to the first trial, and through the appeals process until a final sentence, can be quite substantial so that a large proportion of individuals under the supervision of the penal system are in this category and hence qualify for EM. In the Province of Buenos Aires, up to 84 percent of detainees did not have a final sentence during our sample period. Since its inception, and until October 2007, more than 910 alleged offenders were at some point under electronic surveillance. This means that, with only 300 bracelets and allowing for some administrative delays particularly early in the sample, the average spell on EM in our sample is 420 days.

The formal process of allocating a bracelet is, broadly, as follows (see fig. 2 for a time line that summarizes the main stages). When a person is arrested by the police, the prosecutor is notified (stage 1 in fig. 2). He or she is in charge of running the investigation and ultimately presenting the accusation at the trial. Within a maximum of 48 hours, the prosecutor has to free the alleged offender or order that the apprehension be converted into a detention (if it is reasonable to think that a case against him can be built). The majority of cases are immediately converted because they involve flagrance (i.e., individuals apprehended while they commit crimes), and the alleged offender is put in the local jail (stage 2 in fig. 2).${ }^{14}$ Also at the time of arrest, the case is assigned to the judge who is on duty that day in that judicial district. Thus, the identity of the judge who will be put in charge varies depending on which court was on duty in that district on the day of the apprehension (there is only one judge in each court; we use court/judge interchangeably). One turn on duty lasts for 1 or 2 weeks, and turns are assigned by a lottery at the judicial district (the province is divided into 18 judicial districts). Thus, the allocation of alleged offenders to judges is exogenous to his characteristics. $^{15}$

\footnotetext{
${ }^{14}$ One informant explained that a common description of the system is that "it detains only criminals that crash into police cars." Marchisio (2004) finds that, in a sample of the cases that enter the judicial system in the city of Buenos Aires, 94 percent refer to criminal acts that took place in the previous 24 hours and interprets this as evidence of the prevalence of flagrance in the system. A high official at the Ministry of Justice described criminal investigations as "chaotic" and noted, "We have to start investigating in order to detain, instead of detaining in order to investigate" ("Criminals Are Defeating Us," La Voz del Interior, October 21, 2008).

${ }^{15}$ In theory, a criminal could find out who the judge is on duty on a given day prior to committing a crime. In practice, this possibility seems remote. First, it is not always trivial to obtain this information. Second, key informants reported to have never heard of such a
} 
TABLE 1

Type of Crime for the Electronic Monitoring and Prison Population, 1998-2007

\begin{tabular}{|c|c|c|c|c|c|}
\hline \multirow[b]{2}{*}{ Type of Crime } & \multicolumn{2}{|c|}{$\begin{array}{c}\text { OFFENDERS } \\
\text { RELEASED FROM EM } \\
\end{array}$} & \multicolumn{2}{|c|}{$\begin{array}{c}\text { OFFENDERS } \\
\text { RELEASED FROM } \\
\text { PRISON } \\
\end{array}$} & \multirow{2}{*}{$\begin{array}{c}\text { DIFFERENCE } \\
(\%)\end{array}$} \\
\hline & Frequency & Percent & Frequency & Percent & \\
\hline Homicide & 30 & 7.77 & 1,399 & 5.84 & 1.93 \\
\hline Attempted homicide & 8 & 2.07 & 398 & 1.66 & .41 \\
\hline Sexual offenses & 10 & 2.59 & 448 & 1.87 & .72 \\
\hline Other serious crimes & 10 & 2.59 & 482 & 2.01 & .58 \\
\hline Aggravated robbery & 224 & 58.03 & 11,647 & 48.58 & 9.45 \\
\hline Attempted aggravated robbery & 12 & 3.11 & 1,814 & 7.57 & -4.46 \\
\hline Robbery & 25 & 6.48 & 2,930 & 12.22 & -5.74 \\
\hline Attempted robbery & 22 & 5.7 & 1,922 & 8.02 & -2.32 \\
\hline Possession of firearms & 18 & 4.66 & 1,102 & 4.6 & .06 \\
\hline Larceny/attempted larceny & 4 & 1.04 & 889 & 3.71 & -2.67 \\
\hline Other minor crimes & 23 & 5.96 & 945 & 3.94 & 2.02 \\
\hline Total & 386 & 100 & 23,976 & 100 & \\
\hline
\end{tabular}

NотE.-Distribution by type of crime of all male alleged offenders below 40 years of age with complete data released from the Buenos Aires penal system before reaching a final sentence from January 1, 1998, until October 23, 2007.

The prosecutor gathers the police reports and any other evidence he or she thinks might be relevant, including a description of the alleged crime and a report on how the detainee pleads. It also includes a report on the alleged offender's criminal history produced by the Ministry of Justice and Security, although it is typically limited to previous crimes committed at the province level and only if there was a sentence. Remarkably, if he was imprisoned but freed even 1 day before he was to be sentenced, he would still have a clean criminal record (which is relevant given that the vast majority of those imprisoned do not reach trial). Of course, the judge could request information on previous entries to the province's penitentiary system or even entries to the systems of other provinces. This is often the case, although presumably judges who do request this information place more weight on the victim's rights (conservative judges). ${ }^{16}$ Within 20 days, which can be extended by another 20 , the prosecutor must present a request to the judge that the detainee be incarcerated until trial. With the alleged offender still detained in a local jail, the judge has up to 5 days to decide on this request (stage 3 in fig. 2). If the judge grants the request, the alleged offender is transferred to a prison until trial (the term in Spanish is prisión preventiva: "preventive

case. When asked to suggest how this could happen, one informant answered that it could perhaps apply to sophisticated criminals - operating in bands - but that he himself had not heard of it. Note that drug trafficking is a federal offense and is not part of our sample.

${ }^{16}$ One awkward consequence of this institutional feature is that very ideological judges on the liberal end of the spectrum would end up making decisions with less information than is readily available. 


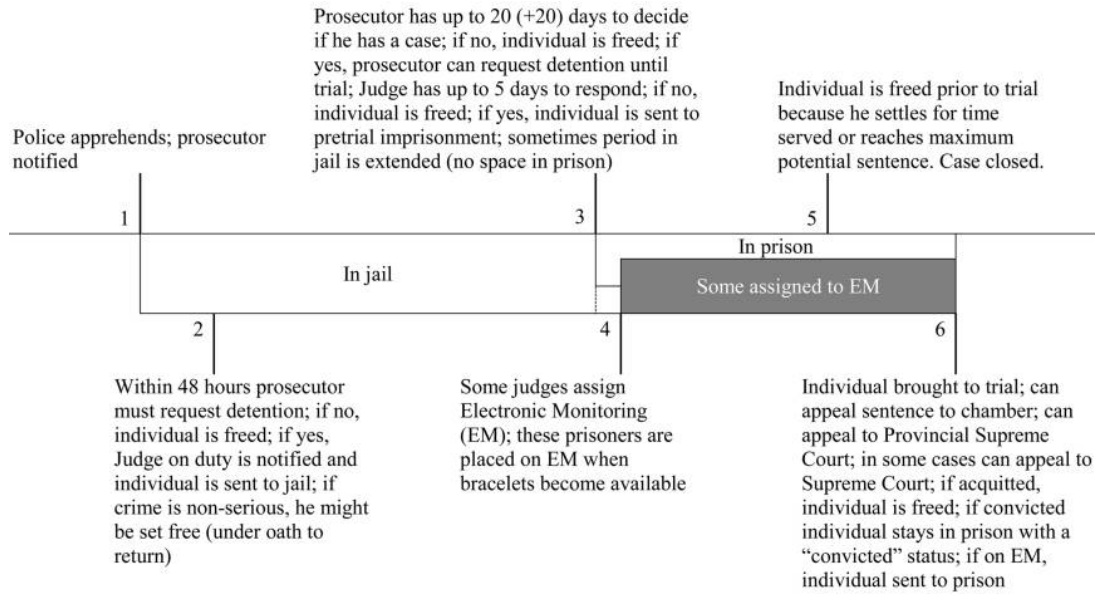

FIG. 2.- Theoretical time line for an alleged offender on pretrial supervision. Our sample comprises stages $1-5$ only.

imprisonment"). The main criterion for a positive answer is that the alleged offender represents a flight risk. Legally, there is one other possible concern to the judge, which is that the alleged offender might interfere with the investigation. This intends to cover the possibility that the alleged offender might locate and threaten the witnesses.

In theory, the legal code allows for the use of bail. In practice, however, it appears to be rarely used. While we confirmed this from several sources, the reasons invoked varied somewhat. The most often-cited reason is that the amount of bail has to be guided by the offender's socioeconomic status. Given that the overwhelming majority of cases involve alleged offenders of very limited economic means, this aspect of the penal code translates into a very low upper limit to the amount of bail that is permissible. Such levels of bail do not offer magistrates any reassurance that alleged offenders, often caught in the act, will return and subject themselves to trial. One alternative is to free alleged offenders after they make an oath to come back, although it appears to be used only in the case of minor crimes, such as larceny. There are also legal restrictions to granting bail to detainees accused of serious crimes: the penal code stipulates that bail (of either type: real or through an oath) cannot be granted, with some exceptions, if the alleged crime has a minimum penalty that is over 3 years (or a maximum penalty that is over 8 years).

Note that this suggests that we should tend to have relatively few people in the sample that end up in preventive imprisonment for larceny and other minor crimes. The evidence is broadly consistent with a more infrequent use of bail for harsher crimes. For example, table 1 suggests that relatively few prisoners have been charged with larceny and 
other minor crimes (only 7.6 percent of the sample), which is comparable to the proportion imprisoned for the most serious crimes (homicide and attempted homicide sum up to just over 7.5 percent). If, as it is reasonable to assume, minor crimes are more prevalent than serious crimes, one possible explanation for this pattern is that individuals accused of larceny are given bail and hence do not enter the database of the penitentiary system reported in table 1. Similarly, one might expect that those who were denied bail and enter the Buenos Aires prison system accused of larceny represent higher risks (conditional on the crime category) than those accused of crimes for which bail is not used. The evidence is again consistent with this, as the percentage of people with a criminal history who are imprisoned for larceny (43 percent) or other minor crimes (37 percent) is almost double the percentage of those accused of homicide ( 15 percent) or aggravated robbery (22 percent). This evidence is only suggestive, so we return to the issue of bail once we introduce more data in Section III.B.

Once judges rule on pretrial imprisonment, they can decide, at their discretion, to "attenuate" it by granting EM (stage 4 in fig. 2). There are three new legal requirements at this stage: a "technical" report on the availability of a telephone line and the suitability of the house to install EM, a "social-environmental" report on the family and neighborhood, and a declaration of a family member accepting to take care of the alleged offender. These seem fairly bureaucratic as our informants suggested that they seldom stand in the way of EM allocation (given the enormous desirability of EM relative to prison). ${ }^{17}$

A real and major final problem is the possibility that EM equipment may not be available. If this is the case, the detainee is added to a waiting list. The list is unique (for the whole province), with no quotas per judicial district, judge, or type of crime. The sources we consulted reported that the judge typically does not request information on its length at the moment of deciding on EM assignment. The legal files of all the individual cases we consulted did not contain such requests prior to the decision to allocate EM. ${ }^{18}$

Note that a recurrent problem is the unavailability of space in prisons. This means that the initial period of detention in jail is sometimes extended and can last several months (until prison space opens up). Thus, in practice, such pretrial detention in jail can occur even after the judge's order of preventive imprisonment (i.e., even after stage 3 in

\footnotetext{
${ }^{17}$ Note that one requirement is that the offender has access to a telephone (and this is a hard constraint in the sense that no amount of goodwill from social services can substitute for this). Early in the program the system required a fixed line, although later cellular phones (with GPS incorporated to guarantee that they are physically "fixed") were also allowed. Obtaining a telephone is relatively cheap. The telephone company confirmed that within a maximum of 30 days a fixed connection could be obtained in urban areas of the Province of Buenos Aires. Obtaining a cellular phone is often cheaper (and immediate).

${ }^{18}$ In the Buenos Aires legal system all communications between the judge and the provincial Penitentiary Service are included in these files.
} 
fig. 2). This means that, even late in the sample period, some alleged offenders on EM do not spend time in prisons (they can go directly from jail to EM). Together with those who went directly to EM because there was equipment available (early in the sample period), almost 40 percent of alleged offenders on EM spent no time in prison.

Following the decision to imprison alleged offenders and to send some of them to EM, individuals must await trial. Given the slow functioning of the legal system, the evidence eventually available to the prosecutor "decays," which means that it is less likely to be available during trial in its original form (one often-cited example is that, as time goes by, witnesses are more likely to forget or confuse details, or even choose to recant their statements). Thus, at some point the prosecutor prefers to settle and free the alleged offender rather than go to trial with odds that appear increasingly unattractive. Given the option to go free or wait an uncertain amount of time for a trial with still an uncertain outcome, most alleged offenders accept the offer (stage 5 in fig. 2). Some alleged offenders reach trial and then exhaust the appeals process receiving a final sentence (they are those at stage 6 in fig. 2). These are not included in our sample (see n. 31). Less than 3 percent of the alleged offenders that were at some point on EM left the program because they received a sentence.

\section{B. Background and Some Anecdotal Evidence on Ideological Differences across Judges}

Although the Argentine legal system de jure gives less discretion to judges than in common-law countries, de facto judges appear to have ample room to express their views (on discretion in legal systems, see La Porta, Lopez-de-Silanes, and Shleifer [2008]). Heterogeneity in views comes from a combination of ideology and practical considerations. Of particular relevance in the case of Argentina is differences across judges over what to do with individuals typically caught in the act and, hence, with a strong presumption of guilt, before they receive a final sentence. Indeed, given the slow rate at which alleged offenders are brought to trial, a pressing decision for judges is what to do with these individuals from the moment they enter the oversight of the penal system until they either are released or receive a final sentence (and, therefore, their imprisonment is no longer "preventive"). Note that the vast majority of cases are in the first category, with release coming when offenders either reach the maximum length of their potential sentence (and they would be released even if found guilty) or settle for time served.

Two extreme judicial positions have been widely reported in the media: garantistas versus mano dura. In the US context, these would broadly correspond to the debate between liberal and conservative judges. Liberal judges in Argentina (i.e., garantistas) often take the position that 
long periods of imprisonment before trial, particularly when prisons are in poor shape, violate basic human rights and thus should be rarely used. Thus, individuals who have not exhausted the appeals process and do not have a final sentence, and hence are formally still innocent, should typically be either free or under minimum supervision.

On the other hand, conservative judges in Argentina (i.e., mano dura) typically emphasize in their rulings the rights of victims and their families. They certainly consider prisons to be in bad shape but not out of line with other problems in the country and largely out of their sphere of influence. Moreover, they take the position that individuals coming before them are already likely to be guilty: given that the police does not cast a very wide net, it brings to the attention of the legal system only cases in which there is flagrancy or other clear evidence against the alleged offender. Such "presumption of guilt" is consistent with the fact that the system never reaches a conclusion on the guilt or innocence of the vast majority of the individuals it decides to imprison (see, e.g., the description in Marchisio [2004]).

Interestingly, while in other countries there has been an attempt to harmonize treatment so as to remove the arbitrary component of the judge's identity (e.g., sentencing guidelines have been adopted to encourage sentencing consistency in the United States and the United Kingdom), these are absent in Argentina. ${ }^{19}$ The result is an institutional setting in which judges have very different criteria when it comes to assigning EM. Liberal judges regularly assign it, while conservative judges never do so.

The rhetoric used is consistent with these differences. As an illustration of the liberal position, consider the case of Eugenio Zaffaroni, a Supreme Court judge who explains that EM violates basic human rights and introduces the danger that we could all be monitored in a prison society, but that it should not be denied to individuals detained without a sentence whose only alternative is confinement in overcrowded prisons. Or consider Judge Schiavo, who stated that "denying EM because a person is 'dangerous' would violate the law and the Constitution." Judge Schiavo is noteworthy because a detainee to whom he had assigned EM in spite of a violent prior conviction (involving a triple murder) went on a killing spree in an episode known as the "Campana massacre," which led to the suspension of the EM program in October 2008 (see Sec. V below). ${ }^{20}$

\footnotetext{
${ }^{19}$ In the United States, e.g., there are attempts to reduce such disparities (e.g., through sentencing commissions and presumptive sentencing guidelines; see Morris and Tonry 1990). An example is the grid of the Minnesota sentencing guidelines, which gives the presumptive sentence for each type of offense/criminal history combination.

${ }^{20}$ See "EM Is Today's Shackle with a Bloody Iron Ball" by Eugenio Zaffaroni in Critica (October 1, 2008) and "Should Judge Schiavo Stand Trial?" by María Ripetta, Luciana
} 
As an illustration of the conservative position, consider the statement of Judge Ramos Padilla when rejecting the pretrial release of an individual accused of robbery with 15 prior entries to the penal system: "I am unwilling to face the accused again if he were in the future to be accused of murder during a robbery, and to have to give explanations to the family of whomever might be his victim." ${ }^{21}$ Another illustration comes from simply noting the frequent political demands for judges to be more punitive. ${ }^{22}$

\section{A Model of EM Assignment}

Consider a judge facing a defendant with characteristics $x$ who must decide on pretrial detention in a prison or under EM. There is no bail. The judge faces a trade-off: if she assigns the defendant to EM, the defendant may escape with probability $p(x)$ and, conditional on escaping, will cause harm to others that generates expected political (and other) costs for the judge of $H(x)$, with $p^{\prime}>0$ and $H^{\prime}>0$. If the judge assigns the defendant to prison, there is no risk of escape, but the judge experiences a utility differential, $d$, when she sends someone to prison who could have been treated less harshly. The parameter $d$ captures the judge's ideology: it may be positive for some judges who enjoy being punitive, but for many, $d$ will be negative because they prefer a more humane punishment option. Thus, given her taste parameter $d$, the judge will assign the defendant to EM if

$$
-p(x) H(x)>d
$$

This simple condition has three implications. First, differences in preferences concerning the desirability of punitive treatment for prisoners create differences in EM use holding $x$ (defendant characteristics)

Geuna, and Santiago Casanello in Critica (October 5, 2008). Schiavo's statement to the media regarding the inadmissibility of using evidence on "dangerousness" at the time of deciding on conditions of pretrial detention was made after the Campana massacre.

${ }^{21}$ He then added, "I can't make a generalized criticism of colleagues who probably take into account the shortcomings of prison institutions, the lack of resources of the judicial system, the excessive work load, and the deficiencies in some laws, and then proceed to take responsibility for situations that, at the end of the day, correspond to other branches of the State" ("Judge Rejects Freedom-Pending-Trial and Criticizes 'Garantista' Colleagues," El Dia, October 3, 2009).

${ }^{22}$ One example is former President Nestor Kirchner, who attacked magistrates for "liberating and liberating criminals" "It Is Time for the Judicial System to Put On the Long Trousers," La Nación, October 30, 2008). Supreme Court judge Eugenio Zaffaroni, a Kirchner appointee, replied, "Some hypocrites expect that everyone is locked up and that judges act as executioners of the poor and the excluded. They ask that children are sentenced to prisons where they will be raped so that they emerge as psychopathic killers" ("Kirchner Is Badly Mistaken," Crítica, November 2, 2008). 
constant. Second, judges with $d>0$ will never use EM because they prefer punitive punishment. Third, with $d$ held constant, the use of EM declines with flight risk, $p(x)$, and the expected harm given flight, $H(x)$.

It is worth mentioning that similar conclusions emerge if there are several judges, all drawing alleged offenders from the same pool of individuals (with potentially similar characteristics). Furthermore, the setup can incorporate rationing of EM bracelets, when judges are not acting strategically (and they are equally optimistic about success at the EM assignment stage). For example, it can include weights on the two sides of the equation above that reflect the fact that assigning someone to EM has a smaller impact on flight risk because he must wait in detention to get a bracelet, and assigning someone to prison involves a smaller expected change in how harshly the defendant will be treated since, under EM, he will likely spend time in jail and possibly prison before receiving a bracelet.

\section{Data, Empirical Strategy, and First Stage}

In this section we present our data and discuss evidence that justifies the assumptions required for an instrumental variables empirical strategy.

\section{A. Data}

Our aim is to compare the effect of EM with the effect of imprisonment on criminal recidivism. Our data were compiled from two sources within the administrative records of the Penitentiary Service of the Province of Buenos Aires. Broadly, the first data source provided information regarding prison versus EM assignment, whereas the second source provided the bulk of the data on recidivism.

Specifically, the first data source, which could be called the selection sample, provides information on the identity and characteristics of all offenders released from the Buenos Aires penal system from January 1, 1998, until October 23, 2007, which is the date when we were allowed to start collecting the data. From this database we obtained two groups. The first group (the EM group) is made up of individuals whose last period under the supervision of the penal system was spent under electronic monitoring. Given that the involvement in criminal activity is mainly a male phenomenon and declines with age (see, e.g., Hansen 2003; Bushway and Piehl 2007), we focus on men below 40 years of age (born after January 1, 1957). We also exclude from the sample offenders who died while under EM, those who were sick or characterized as dangerous, and those with missing data on the specific type of crime, the intervening judge, their birth date, their detention date, or their release date. This gives an EM group of 386 individuals. As mentioned above, the average spell on EM is 420 days (standard deviation 349). 
The second group (the comparison group) is constructed using a similar criterion. It starts with the group whose last period under the supervision of the Buenos Aires penal system was spent in prison. We first exclude a few inmates hosted in the provincial penitentiary system but under federal jurisdiction (as they would not qualify for EM). We then restrict to males below 40 years of age and exclude those who passed away, the sick, those characterized as dangerous, and those with missing data. We then exclude 4,788 released sentenced inmates as they do not qualify for EM. ${ }^{23}$ This leaves a sample of 23,976 alleged offenders who were released from prisons without a final sentence. Table 1 shows the pattern of crimes for these two populations, which total 24,362 individuals. A unique feature of the Argentine system is immediately apparent: many of the offenders under EM are being prosecuted for serious offenses. A second feature visible in table 1 is the apparent similarity in the distribution of alleged offenses for the EM and prison groups (we return to this in Sec. III.B below).

This source of data does not have information on current inmates, so it is not a good source on recidivism. It provides data on recidivism for only one subgroup: those who were imprisoned in the past but are not currently in prison. Thus, in order to complete our measure of recidivism, we use a second data source, which has data on current inmates. It is not publicly available and was kept separately. When we approached the Buenos Aires Penitentiary Service with our request to access this second data source, which can be called the recidivism sample, it was granted (after several requests) under the condition that the data be copied by hand. This meant that copying the information for the full sample with only three authorized research assistants was impractical. We then decided on the following matching criteria (which still implied an inordinately long collection process). For each prisoner in the first group (released from EM), we identified all those prisoners with similar age ( \pm 6 months), similar imprisonment date ( \pm 6 months), similar imprisonment length $( \pm 20$ percent), same type of crime, similar judicial status (our sample involves only detainees who have been sent to prison or EM and have been released before reaching a final sentence), and the same number of episodes of previous imprisonment. Finally, from this group (the matching group of prisoners identified for each offender under EM), we randomly selected three individuals for each individual released from EM. Note that we can select matches from a large group of former prisoners (on the practical difficulties of the "curse of dimensionality," see Nagin et al. [2009]).

\footnotetext{
${ }^{23}$ The low percentage of individuals released with a sentence ( 16.6 percent) is consistent with other data sources.
} 
This second source used in constructing the recidivism sample had more detailed information (besides recidivism). This allowed us to reconfirm the information we had already collected and to correct multiple entries (when individuals reoffending had been given slightly different names on the second entry into the penal system). This procedure gave us complete information for a total database of 1,526 individuals (1,140 formerly in prison and 386 formerly under EM). Note that after this detailed source is used as a filter, the remaining data are no longer exactly matched (2.95:1 instead of 3:1).

\section{B. Evidence on Judge Heterogeneity and the First Stage}

A first pass at the data suggests that several individuals on EM have been accused of very serious crimes. Table 1 provides the distribution of crimes for individuals under EM. There are 30 individuals accused of homicide, which constitutes 7.8 percent of the EM sample. There are also 224 individuals on EM who stand accused of aggravated robbery, which constitutes 58 percent of the EM sample. This suggests that neither the severity of the crime nor the expected recidivism risks are strong criteria for EM assignment. ${ }^{24}$

Table 1 also contains the types of crimes committed by the prison subsample. For example, there are 1,399 imprisoned individuals accused of homicide, which is 5.8 percent of the sample. For attempted homicide, the number is 398 (1.7 percent). These numbers are remarkably close to those in the EM sample (compare with 7.8 percent and 2.1 percent, respectively). Judges do not appear to be selecting the "kind" types to send to EM: the difference across the two samples is not large, particularly in the serious categories. We also observe that a history of trouble with the law does not stand in the way of EM assignment, as several alleged offenders on EM had at least one previous entry into the penal system.

The observed assignment to EM is not the product of a uniform tendency across judges. Instead, some judges in the sample tend to assign EM more frequently than others. From a universe of 293 judges acting on the 24,362 cases we analyze, only a third of them (100) have ever used EM. Thus, two-thirds of judges never used EM when it was available to them, whereas the other third send 2.68 percent of the alleged offenders standing before them to EM. This is consistent with ideological judges (constrained by the 300 bracelet limit). Hence, we construct a measure of the intervening judge's liberal ideology, \% judge sent to EM,

${ }^{24}$ Robbery is the category with the highest recidivism rate in our sample. In the United States, Langan and Levin (2002) report that robbery has one of the highest rearrest rates, although the classification is somewhat different. 
defined as the proportion of all alleged offenders who stood before the intervening judge that were assigned to EM-excluding the individual in question. Of course, this is a noisy measure: some judges might have used EM initially to experiment or under an incomplete understanding of its implications and subsequently decided not to use it. Alternatively, some judges who appear as not having sent anyone to EM might have done so but were unsuccessful in obtaining it given the small capacity of the EM program.

Table 2 exploits the information on the intervening judge's ideology to investigate an alleged offender's tendency to receive EM in the selection sample. We focus on judges with at least 10 offenders (the sample drops to 24,003). ${ }^{25}$ Column 1 of table 2 reports that EM assignment (the dependent variable is a dummy equal to one if the alleged offender received $\mathrm{EM}$ ) is positively correlated with \% judge sent to EM, controlling for judicial district dummies. The implied effect is large: a one standard deviation increase in the judge's EM rate (0.067) would imply an increase in the likelihood of EM assignment of $0.044(0.663 \times 0.067)$. Since the proportion of alleged offenders on EM in the sample for column 1 is 0.016 , the increase is 280 percent of the mean EM rate in our sample.

Column 2 in table 2 includes the crime category for the most serious alleged offense (the omitted category is homicide). We note that the seriousness of the alleged offense has no predictive power, and, in fact, those accused of homicide are, if anything, more likely to receive EM than those accused of less serious crimes (the difference with larceny, e.g., is significant). To the extent that the crime category adequately captures the risk of flight, this result is inconsistent with the model presented in Section II.C. The adjusted $R^{2}$ remains almost unchanged between columns 1 and 2. As a benchmark, we note that the adjusted $R^{2}$ of a baseline regression of EM assignment exclusively on judicial district fixed effects is .028. Similarly, when such a baseline regression includes both district fixed effects and the alleged offense categories (but excludes \% judge sent to EM), the adjusted $R^{2}$ is .029. Thus, our instrument contributes to the model's fit more than the dummies capturing the seriousness of the imputed offense (the adjusted $R^{2}$ jumps from .028 to .042, vs. .029).

Column 3 includes the alleged offender's criminal history and reveals a negative and marginally significant coefficient. Although it is unclear why the severity of the crime should have such a different impact on the judge's evaluation of flight risk than criminal history, we note that the $R^{2}$

\footnotetext{
${ }^{25}$ By construction, judges who use EM are overrepresented in the recidivism sample (100 out of 190). Once we focus on judges with more than 10 offenders, there are 97 judges using EM out of 172 .
} 


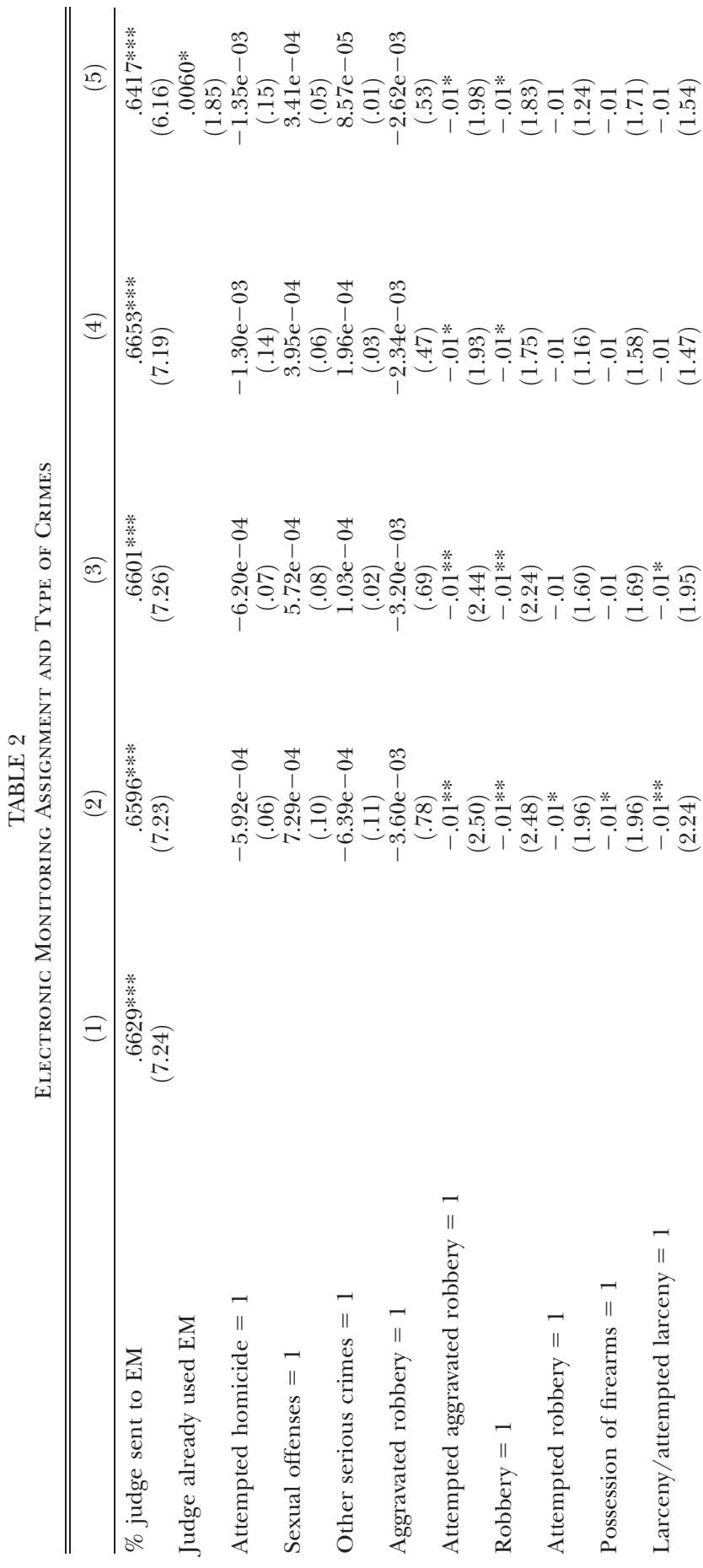




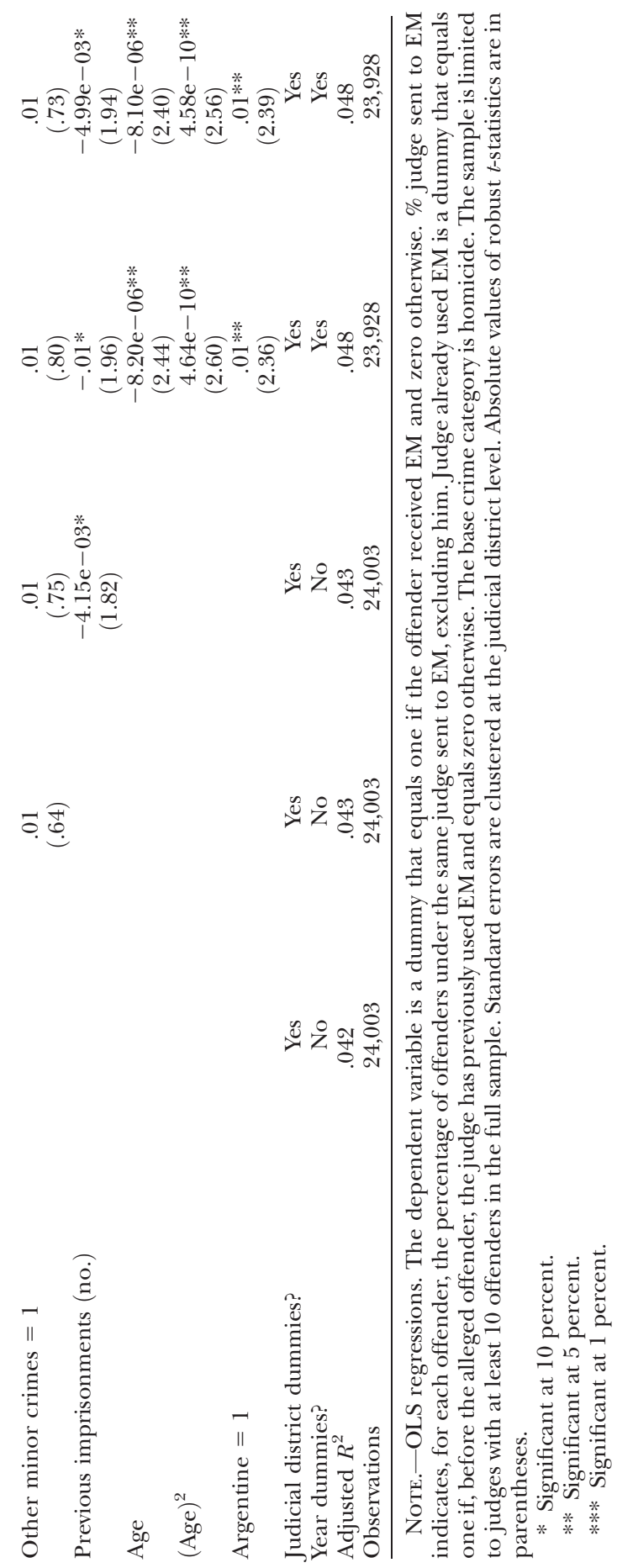


remains unchanged. ${ }^{26}$ Importantly for our purposes, the coefficient on $\%$ judge sent to EM is unaffected by the inclusion of the crime categories or the alleged offender's criminal history as controls. Column 4 includes other personal controls that are available and reaches a similar conclusion. Finally, in column 5 we add a proxy for the judge's ideology incorporating a time dimension: judge already used EM, a dummy that equals one if the judge has ever previously sent an alleged offender to EM prior to facing the particular individual and equals zero otherwise. This instrument is also marginally significant, reinforcing the idea that judges' preferences affect EM assignment.

Finally, we can explore more formally if the evidence is consistent with the assumption of random assignment to judges. While it is not possible to test whether alleged offenders standing in front of conservative judges are particularly "mean" (because this involves an unobservable trait), we can study if their observable characteristics differ from those of alleged offenders standing in front of liberal judges. Accordingly, table 3 presents the observable characteristics of alleged offenders in our sample across liberal and conservative judges, where "liberal" is defined as having \% judge sent to EM above the median in the sample. ${ }^{27}$ In column 1 , we have the unconditional mean of the covariates for conservative judges. We would like to make comparisons taking into account district fixed effects, which correspond to heterogeneous geographical units and which are the level at which the randomization takes place. A simple way to present the data, following Aizer and Doyle (2011), is to have in column 2 the predicted mean (adjusted to control for the effects of the judicial district dummies). These emerge from separate ordinary least squares (OLS) regressions for each covariate on a dummy for whether the intervening judge was above the median (i.e., liberal) and district dummies. These are estimated in the selection sample of 24,003 observations. Consistent with random assignment of alleged offenders to judges on duty within each district, the means of the characteristics of the cases standing in front of liberal and conservative judges are remarkably similar.

Alleged offenders across the high-EM and low-EM samples have similar dates of entry into the supervision of the penal system and are heard in courts of similar size. They are predominantly Argentine (98 percent); on average, they enter supervision when they are 25.3 years old; and approximately one in four have a previous entry to the province's Peni-

\footnotetext{
${ }^{26}$ We note that some garantista judges have argued that it is unconstitutional to use either dimension as a criterion in the allocation of EM (e.g., see the quotation of Judge Schiavo in Sec. II.B above).

${ }^{27}$ As the distribution of the instrument is strongly asymmetric, with many observations at zero, we use the median as a measure of centrality. Similar results are obtained using the mean (in fact, there are no significant differences among the 23 categories).
} 
tentiary Service. Given that some offenders have multiple previous entries, the average number of previous imprisonments is 0.4 (this includes both previous entries that end up in a final sentence and entries in which the individual spent all his time in pretrial imprisonment). Again, the difference is not significant across cases standing before judges with low EM and high EM rates. For a subsample of 14,635 observations, we also have an indicator of the alleged offender's profession, which is matched to the average income that this profession earns in the General Household Survey. Although care should be exercised given the imprecise nature of these data, column 3 reports no significant difference across the high- and low-EM samples. An indicator of whether the alleged offender has a spouse or partner is available for a subsample of 19,697 observations and also reveals no significant differences across columns 1 and 2.

The cases standing before the two types of judges involve very similar alleged offenses. The difference is significant in only one category, and it is small in size. Furthermore, it does not appear to involve a clear difference in severity and does not suggest that the distribution of crimes in the cases faced by high-EM judges is dominated by less serious cases. The final rows of table 3 investigate this further by comparing measures of the severity of the crime of the alleged offenders facing the two groups of judges. The first three measures - serious crimes, middle crimes, and minor crimes - reveal no differences. Specifically, minor crimes is a dummy that equals one for prisoners whose most serious crime is larceny, attempted larceny, or other minor crimes and zero for any other crime. There are no significant differences. Note that this test also provides indirect evidence on the differential use of bail because cases in which bail was granted do not enter our database. If bail were in fact in widespread use, liberal judges would presumably tend to use it more frequently, so that minor crimes should be higher for conservative judges. The difference (9 percent vs. 8 percent) is consistent with this hypothesis, although it is small and not statistically significant.

\section{Empirical Strategy}

We compare the recidivism rate of the EM and prison population running the following regression model:

$$
R_{i}=a+b E M_{i}+\varepsilon_{i}
$$

where $R_{i}$ is a dummy variable that indicates whether individual $i$ went back to detention in the Province of Buenos Aires after his release, and $E M_{i}$ is a dummy variable that indicates whether individual $i$ was in the electronic monitoring group. We also include as controls type of crime 


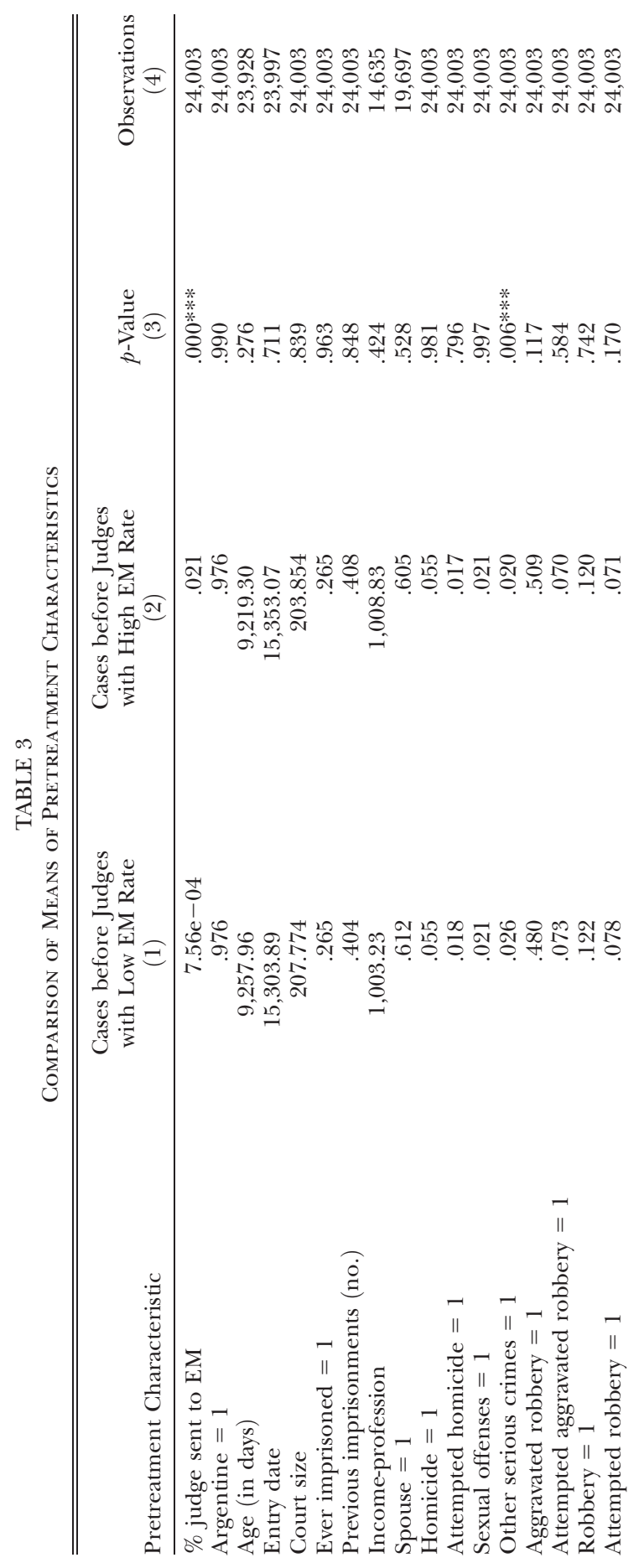




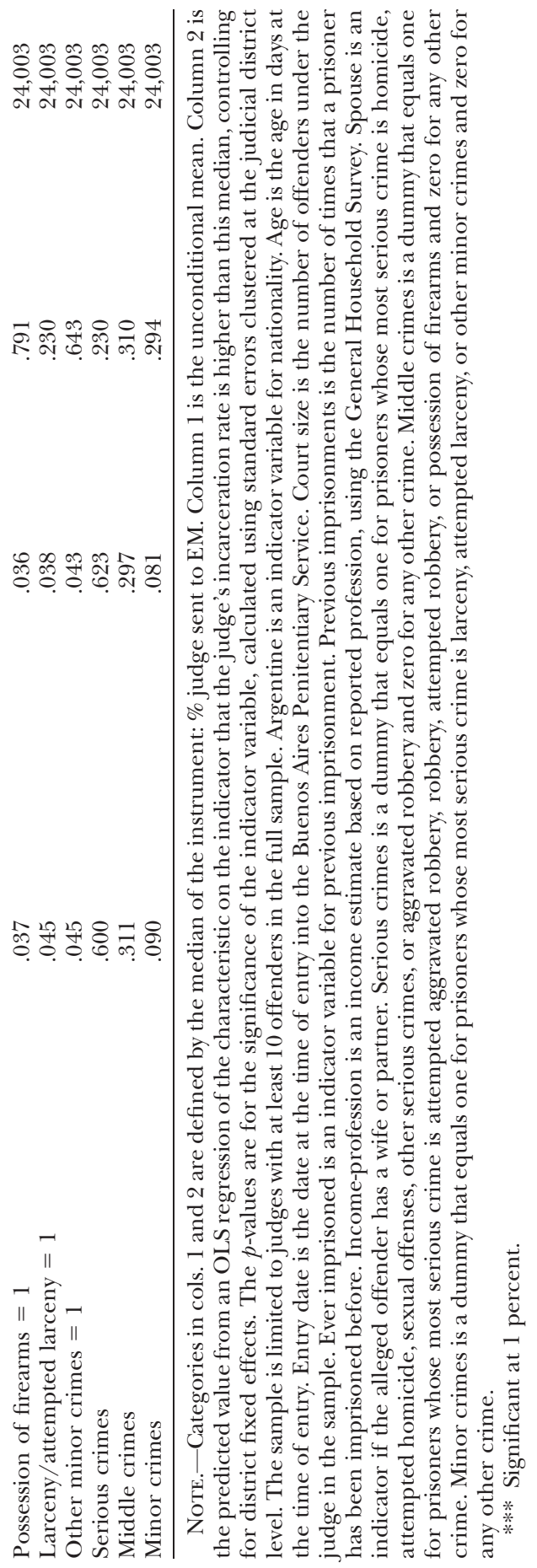


dummies, age, age squared, Argentine, number of previous imprisonments, judicial district dummies, and year dummies (although note that in the recidivism regressions the sample is already matched following some of these same variables). Robust standard errors are clustered at the judicial district level (see Bester, Randi, and Conley 2011; results are similar when we use clusters at the judge level).

An obvious concern with this strategy is that the allocation of EM to offenders is potentially nonrandom. In particular, the concern is that judges try to assign EM to individuals who have a "kind" type or have a lower risk of reoffending following release, so that any difference in the recidivism rates across the EM and prison samples simply captures success at the selection stage. In order to deal with the possibility that such unobservable traits bias the OLS estimate, we rely on an instrumental variables (IV) approach, using an indicator of the judge's ideology as the instrument. The main instrument we use is \% judge sent to EM, the percentage of alleged offenders whom this judge has placed on EM, excluding the individual in question. Given random assignment of alleged offenders to judges within each judicial district, we interpret the IV estimate as the causal effect of EM assignment on recidivism. We also introduce judge already used EM, a dummy variable for whether the judge has previously sent an alleged offender to EM (prior to facing the offender in question), to capture a time dimension of ideology. Instruments are calculated in the original database of 24,362 alleged offenders.

\section{Results}

As a benchmark it is helpful to note that, in the raw data, the prison recidivism rate (i.e., the proportion of individuals released from prison who have returned for another crime) is 22.37 percent $(255 / 1,140)$. It is 13.21 percent for the group of 386 alleged offenders released after spending time under EM, for a difference of 9 percentage points. The period over which we calculate the likelihood of recidivism varies across individuals depending on how early they were released from penal supervision (but note that the EM and prison samples are matched). The end date is common to all individuals, as we collected our data in October 2007. On average, the postrelease period in our sample is 2.85 years. ${ }^{28}$

\footnotetext{
${ }^{28}$ Thus, the average yearly recidivism rate for the prison sample (i.e., the proportion of those released from prison who are back within a year) is $7.8=22.37 / 2.85$, while that for the EM sample is $4.6=13.21 / 2.85$.
} 
A. OLS (and Probit) Results

Table 4 presents a set of basic OLS and probit results as reference. Column 1 runs recidivism on a dummy indicating if the person was released from EM. The coefficient repeats the observation that the difference between the two groups is 9 percentage points. Column 2 presents a regression including the above-mentioned set of controls plus judicial district and year dummies. The coefficient on EM does not change (the sample is matched along these controls, with the exception of the geographic and nationality information). Column 3 repeats the exercise with a probit regression. Column 4 restricts the sample to alleged offenders accused of aggravated robbery, the most common type of crime (and one for which bail, by and large, is not allowed), and finds similar results.

Note that the judge's decision for pretrial imprisonment involves relatively little information (as compared, e.g., to a sentencing decision). Thus, it is possible to argue that the judge does not have much more information than that included in these regressions, pointing to a causal interpretation of the OLS coefficient. While the formal evidence supports this interpretation, it is worth noting that the Buenos Aires legal system has the peculiarity that it does not pass sentence for the majority of alleged offenders. Thus, for all intents and purposes, pretrial imprisonment is the key legal decision affecting alleged offenders; so, informally, it is possible that judges gather more information than that available in the judicial files.

Note that the extent of selection can be studied (albeit indirectly) by including in column 5 in table 4 an indicator for whether the judge has ever used EM. Indeed, there are three groups in the sample: those who were assigned to EM, those who went to prison sent by a judge who uses $\mathrm{EM}$, and those sent to prison by a judge who never used EM. If judges who use EM in fact select the good types (low recidivism risk) for treatment with EM, then those standing before that same judge who were not selected for EM should be bad types (high recidivism). In particular, their average type should be worse than the average type of the conservative judges who did zero selection. In other words, the point estimate on the dummy judge ever used EM should be positive (as the base category is those who were sent to prison by judges who never selected anyone for EM). Instead, this dummy variable is insignificant, with a point estimate of -0.02 . Thus, the implied estimate of the difference in recidivism across former prisoners who stood before the two different types of judges (excluding those who received EM) is suggestive of no selection on the part of judges (although, of course, the size of the EM program would have to be larger for this test to be convincing; when we 


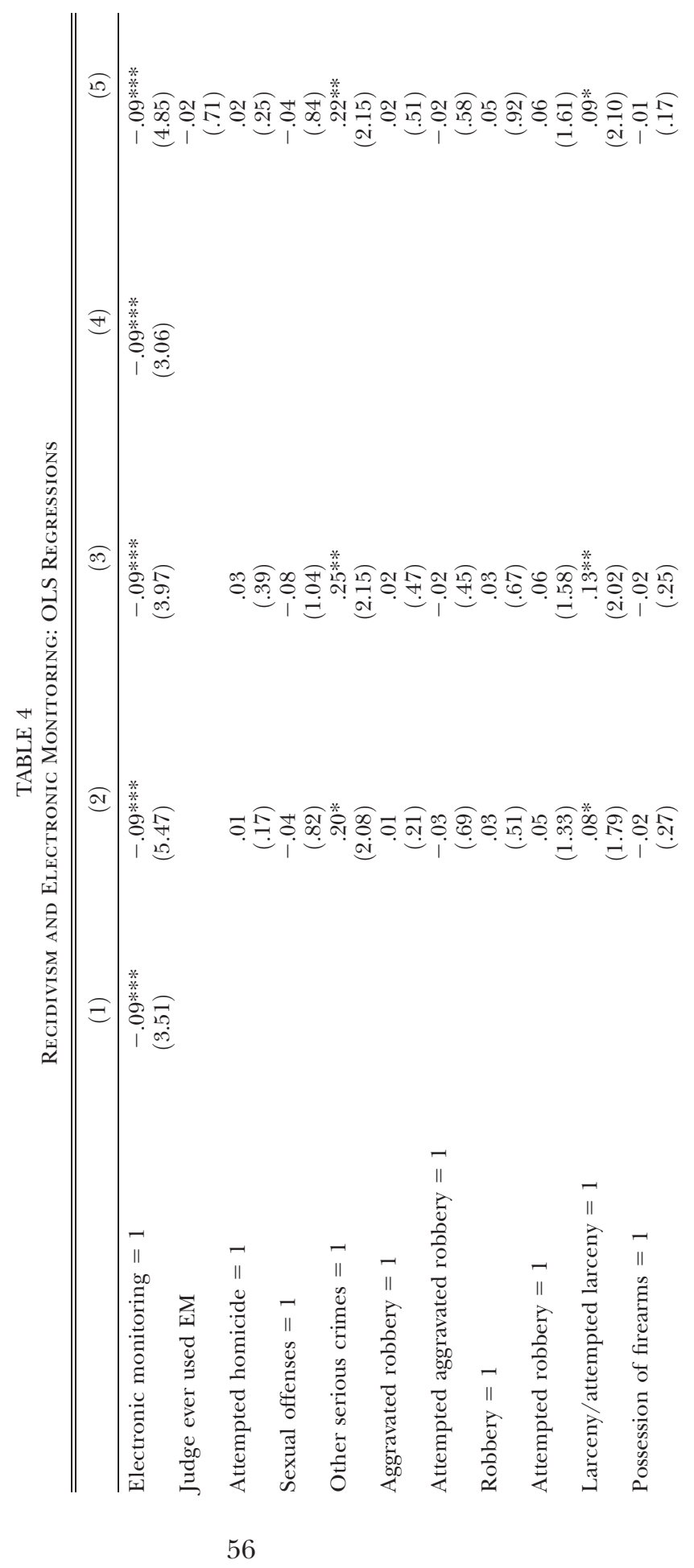




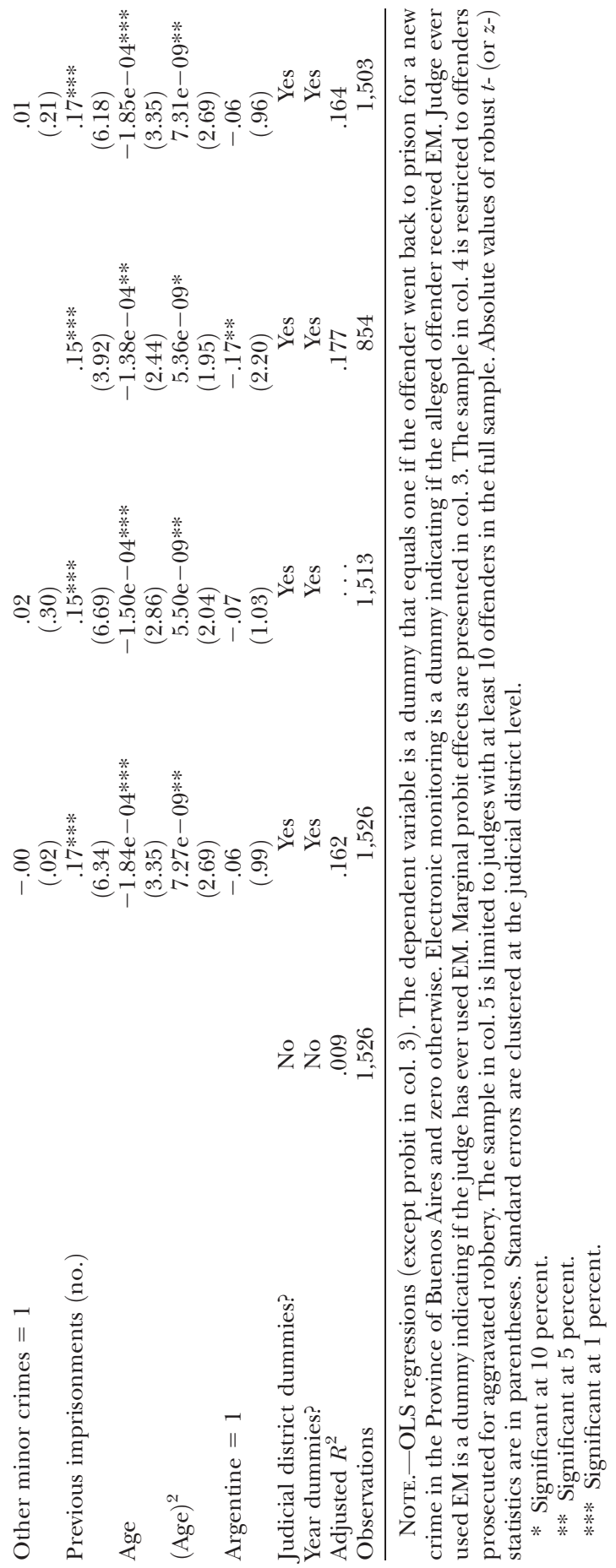


restrict attention to judges with relatively few cases so as to avoid this problem, we reach similar conclusions) ${ }^{29}$

\section{B. Using Judge Ideology to Estimate the Effect of EM on Recidivism}

Column 1 in table 5 uses judge dummies as an instrument (the $F$-statistic for the joint significance is 4.36). There are 172 judges in this sample, so this approach has limitations. Column 2 in table 5 uses as an instrument $\%$ judge sent to EM, the percentage of offenders whom the judge sent to electronic monitoring (excluding each particular offender). We calculate these percentages using the full sample of 24,362 offenders and restrict attention to judges with more than 10 offenders. The coefficient is still negative and significant and somewhat larger in absolute size than the OLS estimate, implying a reduction of about 59 percent of the raw recidivism rate following prison. The instrument is highly significant in the first stage.

Column 3 adds a different dimension of ideology depending on how early the judge started using EM. Both instruments are statistically significant in the first stage. The second stage shows a negative and significant effect of EM on recidivism of -0.16 . We cannot reject equality of the OLS and two-stage least squares (2SLS) estimators at standard confidence levels. In column 4, we combine these two instruments in an IV probit regression, with similar results. Finally, in column 5, we run the same first-stage regression of column 3 not in the recidivism sample of 1,503 observations but in the full sample of alleged offenders of the Buenos Aires penitentiary system where EM bracelets are actually assigned (exactly the regression in col. 5 of table 2 ). We then use the predicted EM assignment from this full-sample regression as an instrument for EM in our recidivism sample..$^{30}$ All these specifications show a negative and significant effect of EM on recidivism of between 11 and 16 percentage points. Even the most conservative estimate is a large effect: 11 percentage points represent a drop of approximately 48 percent of the base recidivism rate of the prison sample. It translates into a difference of 3.85 percentage points in the average yearly recidivism rate for the two samples (i.e., the proportion of those released from prison who are back within a year is $7.84=22.37 / 2.85$, while that for the EM sample is $3.99=$ $11.37 / 2.85)$.

\footnotetext{
${ }^{29}$ Using the raw data to make the same point reveals that the recidivism rate for alleged offenders under judges who never use EM is 22.8 percent $(104 / 457)$. On the other hand, for judges who used EM, the recidivism rates are 22.1 percent $(151 / 683)$ for alleged offenders released from prison and 13.2 percent $(51 / 386)$ for alleged offenders released from EM. Similar results are obtained if we use the median or the mean EM rate to classify judges.

${ }^{30}$ On generated instruments, see Wooldridge (2002, 115-18).
} 
TABLE 5

Recidivism and Electronic Monitoring: IV Regressions

\begin{tabular}{lccccc}
\hline \hline & $(1)$ & $(2)$ & $(3)$ & $(4)$ & $(5)$ \\
\hline Second stage: & & & & & \\
Electronic monitoring $=1$ & $-.11^{* *}$ & $-.13^{* *}$ & $-.16^{* *}$ & $-.11^{* * *}$ & $-.15^{* *}$ \\
& $(2.25)$ & $(2.33)$ & $(2.29)$ & $(2.66)$ & $(2.33)$ \\
Adjusted $R^{2}$ & .16 & .16 & .16 & $\ldots$ & .16 \\
$\begin{array}{l}\text { First stage: } \\
\quad \text { Set of judge dummies? }\end{array}$ & Yes & & & & \\
\% judge sent to EM & & $3.09^{* * *}$ & $2.94^{* * *}$ & $3.11^{* * *}$ & \\
Judge already used EM & & $(9.91)$ & $(9.18)$ & $(9.56)$ & \\
& & & $.05^{* *}$ & .05 & \\
Large-sample estimated & & & $(2.09)$ & $(1.51)$ & $4.73^{* * *}$ \\
$\quad$ EM & & & & & .26 \\
Adjusted $R^{2}$ & .30 & .26 & .26 & $\ldots .10)$ \\
Observations & 1,503 & 1,503 & 1,503 & 1,494 & 1,503 \\
\hline
\end{tabular}

NoTE.--Instrumental variables regressions (IV probit in col. 4, 2SLS in the rest). The dependent variable is a dummy that equals one if the offender went back to prison for a new crime in the Province of Buenos Aires and zero otherwise. All the regressions include as controls type of crime dummies, age, age squared, Argentine, number of previous imprisonment, judicial district dummies, and year dummies. The sample is limited to judges with at least 10 offenders in the full sample. In col. 1, the instruments are a set of dummy variables indicating the judge that tried the offender. The $F$-statistic of the joint significance test of all the dummies in the first stage is 4.36 (significant at 1 percent). In col. 2 , the instrument is \% judge sent to EM, the percentage of alleged offenders the judge sent to EM, excluding him. This and all other instruments used in this table are calculated in the original database of 24,362 alleged offenders. In col. 3 , we add judge already used EM, a dummy that equals one if, before the alleged offender, the judge has previously used EM and equals zero otherwise. In col. 4, we again combine these two instruments in an IV probit regression (marginal probit effects are presented for the second stage). The same first-stage regression of col. 3 is run in the full sample of 24,362 individuals (see col. 5 of table 2), and the predicted EM assignment is the instrument used in col. 5. Absolute values of robust $t$ - (or $z$-) statistics are in parentheses. Standard errors are clustered at the judicial district level.

** Significant at 5 percent.

*** Significant at 1 percent.

One concern with these results is that, although EM could reduce recidivism rates, perhaps those who do recidivate might perceive that "they got it cheap" and then commit harsher crimes (a weakening of the specific deterrence effect). We can study this issue using the minimum and maximum penalties established by the penal code for each type of crime as a cardinal measure of crime severity, now for the recidivistic crimes committed after release from EM or prison. We do not find significant differences in the severity of the crimes committed following release from prison or EM using the minimum sentence, the maximum sentence, or the difference between the sentences for the original crime and the new crime.

Table 6 presents tests exploring the robustness of our results. Columns 1-3 include additional information. Column 1 includes our mea- 
TABLE 6

Recidivism And Electronic Monitoring: Robustness

\begin{tabular}{|c|c|c|c|c|c|}
\hline & (1) & (2) & (3) & (4) & (5) \\
\hline \multicolumn{6}{|l|}{ Second stage: } \\
\hline Electronic monitoring $=1$ & $\begin{array}{l}-.23 * * * \\
(3.13)\end{array}$ & $\begin{array}{l}-.14 \\
(1.70)\end{array}$ & $\begin{array}{l}-.15^{*} \\
(1.92)\end{array}$ & $\begin{array}{l}-.18^{*} \\
(1.87)\end{array}$ & $\begin{array}{l}-.21 \\
(1.55)\end{array}$ \\
\hline Income-profession & $\begin{array}{l}4.47 \mathrm{e}-05^{* *} \\
(2.67)\end{array}$ & & & & \\
\hline Family visits $=1$ & & $\begin{array}{l}.04 \\
(.97)\end{array}$ & & & \\
\hline Spouse $=1$ & & $\begin{array}{c}.04 \\
(1.61)\end{array}$ & & & \\
\hline Total detention length & & & $\begin{array}{l}1.19 \mathrm{e}-04^{*} \\
(1.96)\end{array}$ & & \\
\hline Total detention length ${ }^{2}$ & & & $\begin{array}{l}-4.12 \mathrm{e}-08 \\
(1.15)\end{array}$ & & \\
\hline Adjusted $R^{2}$ & .14 & .15 & .16 & .17 & .16 \\
\hline \multicolumn{6}{|l|}{ First stage: } \\
\hline \% judge sent to EM & $\begin{array}{l}3.28 * * * \\
(8.37)\end{array}$ & $\begin{array}{l}3.36^{* * * *} \\
(10.05)\end{array}$ & $\begin{array}{l}2.93 * * * \\
(9.17)\end{array}$ & $\begin{array}{l}2.71 * * * \\
(6.98)\end{array}$ & $\begin{array}{l}2.90 * * * \\
(8.52)\end{array}$ \\
\hline Judge already used EM & $\begin{array}{l}.03 \\
(1.05)\end{array}$ & $\begin{array}{c}-.02 \\
(.77)\end{array}$ & $\begin{array}{l}.06^{* *} \\
(2.36)\end{array}$ & $\begin{array}{l}.09 * * * \\
(2.66)\end{array}$ & $\begin{array}{l}.05^{* *} \\
(2.08)\end{array}$ \\
\hline Adjusted $R^{2}$ & .28 & .36 & .26 & .26 & .25 \\
\hline Observations & 941 & 1,147 & 1,503 & 829 & 1,441 \\
\hline
\end{tabular}

NotE.-IV regressions based on col. 3 of table 5 . The instruments are \% judge sent to EM (the percentage of alleged offenders the judge sent to EM, excluding him) and judge already used EM (a dummy that equals one if, before the alleged offender, the judge has previously used EM and equals zero otherwise). Both instruments are calculated in the original database of 24,362 alleged offenders. The dependent variable is a dummy that equals one if the offender went back to prison for a new crime in the Province of Buenos Aires and zero otherwise. All the regressions include as controls type of crime dummies, age, age squared, Argentine, number of previous imprisonments, judicial district dummies, and year dummies. The sample is limited to judges with at least 10 offenders in the full sample. In col. 4, we consider only aggravated robbery. In col. 5, the sample excludes escapees. Income-profession is an estimate based on reported profession, using the General Household Survey. Spouse is an indicator if the alleged offender has a wife or partner. Family visits is an indicator that equals one if the prisoner receives a family visit. Total detention length is the total amount of time under detention in prison or EM. Absolute values of robust $t$-statistics are in parentheses. Standard errors are clustered at the judicial district level.

* Significant at 10 percent.

** Significant at 5 percent.

*** Significant at 1 percent.

sure of income, while column 2 attempts to control for the individual's family situation by including an indicator for whether the individual has a spouse and an indicator for whether relatives visit the alleged offender in prison. The results are consistent, but we note that the number of observations drops. Column 3 includes controls for the total extension of pretrial detention (and a squared term), with similar results. Column 4 repeats the basic regression in a sample that includes only those accused of aggravated robbery, the most common type of crime. The results are broadly similar. Finally, in column 5 we exclude alleged offenders who escape while on EM, with again broadly similar results (estimation by IV probit 
reveals a smaller coefficient, significant at the 10 percent level; see also Sec. V.A). ${ }^{31}$

Finally, in table 7 we consider a natural hypothesis: that EM causes lower recidivism within the EM sample. Indeed, the 386 individuals in our EM sample differ in the amount of time they spend on EM, with some alleged offenders spending no time in prison and others spending as much as 98 percent (286 days out of 293 in detention before being released). ${ }^{32}$ One advantage of this comparison is that it involves groups that were all assigned to EM, so the problem of selection is less relevant. The raw data are consistent with the theory that EM leads to less recidivism, perhaps because it is less brutal than prison: when we split the sample of 386 in half using the proportion of time under supervision spent on EM, we find that those who spent a relatively large proportion on EM had a recidivism rate of 9.8 percent (19/193), whereas those who spent relatively little time on EM (and more in prison) had a raw recidivism rate of 16.6 percent $(32 / 193)$. For reference, the raw recidivism rate of the prison sample is 22.4 percent. In column 1 of table 7 we include a simple OLS regression of recidivism on the proportion of time under supervision spent on EM, revealing, as expected, a negative relationship. Unfortunately, it is not statistically significant at conventional levels (significant at 11 percent), so the evidence in favor of this hypothesis, once controls are included, is only suggestive.

\section{Discussion}

\section{A. Escape}

Within our EM sample, 17 percent (66 out of 386 individuals) fled from the supervision of the penal system by breaking their electronic bracelets. ${ }^{33}$ Interestingly, escape occurs at a lower rate for the group that never

\footnotetext{
${ }^{31}$ We had also excluded (see Sec. II.A) seven individuals who spent time under EM but later went back to prison (either because they received a final sentence or because of misconduct). Note that they may distort our estimates if they are particularly "bad types." However, a really bad type would escape supervision altogether and avoid being resent to prison. Escapees do not pose a problem as they count when they commit new crimes (see the discussion below). We run robustness tests including the seven "returnees" and find that even with the most pessimistic assumptions the main results are unaffected. As a backof-the-envelope illustration, note that if we assume that the seven of them recidivate (i.e., commit a crime and are imprisoned) at the rate of the prison sample, the recidivism of the EM sample would rise to 13.4 percent (from 13.21 percent). Assuming a 100 percent recidivism rate, the average EM rate rises to 14.8 percent, so the difference in the raw rates would be 7.2 points (instead of 9 ).

${ }^{32}$ The average spell on EM for the sample that spent time in prison is 376 days (standard deviation 301), while the average spell for those who went directly to EM is 487 days (standard deviation 404).

${ }^{33}$ Given how easy escape is, the seriousness of the original crimes in the EM sample, and the low apprehension rates, this seems a remarkably low number, which may be of broader interest for criminologists. The average spell on EM for those who escape is 211 days (standard deviation 246).
} 
TABLE 7

RECIDIVISM AND EscAPE WITHIN EM

\begin{tabular}{|c|c|c|c|}
\hline & $\begin{array}{l}\text { Recidivism } \\
\text { (1) }\end{array}$ & $\begin{array}{l}\text { Recidivism } \\
\quad(2)\end{array}$ & $\begin{array}{l}\text { Escape } \\
(3)\end{array}$ \\
\hline $\begin{array}{l}\text { EM detention length/total detention } \\
\text { length-prison or EM }\end{array}$ & $\begin{array}{l}-.08 \\
(1.72)\end{array}$ & & \\
\hline Attempted homicide $=1$ & $\begin{array}{l}.11 \\
(.73)\end{array}$ & $\begin{array}{l}.10 \\
(.67)\end{array}$ & $\begin{array}{r}-.09 \\
(.93)\end{array}$ \\
\hline Sexual offenses $=1$ & $\begin{array}{l}.14 \\
(.87)\end{array}$ & $\begin{array}{l}.13 \\
(.82)\end{array}$ & $\begin{array}{r}.22 \\
(1.32)\end{array}$ \\
\hline Other serious crimes $=1$ & $\begin{array}{l}-.08 \\
(1.00)\end{array}$ & $\begin{array}{r}-.09 \\
(.96)\end{array}$ & $\begin{array}{l}.17 \\
(.86)\end{array}$ \\
\hline Aggravated robbery $=1$ & $\begin{array}{l}.01 \\
(.22)\end{array}$ & $\begin{array}{l}.01 \\
(.11)\end{array}$ & $\begin{array}{l}.00 \\
(.05)\end{array}$ \\
\hline Attempted aggravated robbery $=1$ & $\begin{array}{l}.07 \\
(.68)\end{array}$ & $\begin{array}{l}.06 \\
(.58)\end{array}$ & $\begin{array}{l}-.09 \\
(1.25)\end{array}$ \\
\hline Robbery $=1$ & $\begin{array}{c}.14 \\
(1.68)\end{array}$ & $\begin{array}{c}.14 \\
(1.51)\end{array}$ & $\begin{array}{r}-.05 \\
(.27)\end{array}$ \\
\hline Attempted robbery $=1$ & $\begin{array}{r}-.03 \\
(.34)\end{array}$ & $\begin{array}{c}-.04 \\
(.52)\end{array}$ & $\begin{array}{r}-.01 \\
(.15)\end{array}$ \\
\hline Possession of firearms $=1$ & $\begin{array}{c}-.01 \\
(.47)\end{array}$ & $\begin{array}{l}-.03 \\
(1.28)\end{array}$ & $\begin{array}{l}.05 \\
(.39)\end{array}$ \\
\hline Larceny/attempted larceny $=1$ & $\begin{array}{c}-.11 \\
(.76)\end{array}$ & $\begin{array}{r}-.13 \\
(.90)\end{array}$ & $\begin{array}{l}.08 \\
(.45)\end{array}$ \\
\hline Other minor crimes $=1$ & $\begin{array}{r}-.04 \\
(.81)\end{array}$ & $\begin{array}{r}-.05 \\
(.99)\end{array}$ & $\begin{array}{r}-.07 \\
(.80)\end{array}$ \\
\hline Previous imprisonments (no.) & $\begin{array}{l}.11^{* * * *} \\
(4.14)\end{array}$ & $\begin{array}{l}.12 * * * \\
(4.25)\end{array}$ & $\begin{array}{l}.13^{*} \\
(1.84)\end{array}$ \\
\hline Age & $\begin{array}{c}-3.91 \mathrm{e}-05 \\
(.50)\end{array}$ & $\begin{array}{c}-4.43 \mathrm{e}-05 \\
(.54)\end{array}$ & $\begin{array}{l}1.90 \mathrm{e}-05 \\
(.23)\end{array}$ \\
\hline$(\text { Age })^{2}$ & $\begin{array}{l}9.64 \mathrm{e}-10 \\
(.24)\end{array}$ & $\begin{array}{l}1.26 \mathrm{e}-09 \\
(.30)\end{array}$ & $\begin{array}{c}-2.22 \mathrm{e}-09 \\
(.55)\end{array}$ \\
\hline Argentine $=1$ & $\begin{array}{c}.23 * \\
(2.01)\end{array}$ & $\begin{array}{c}.21 \\
(1.74)\end{array}$ & $\begin{array}{c}.11 \\
(1.30)\end{array}$ \\
\hline Judicial district dummies? & Yes & Yes & Yes \\
\hline Year dummies? & Yes & Yes & Yes \\
\hline Adjusted $R^{2}$ & .15 & .14 & .03 \\
\hline Observations & 386 & 386 & 386 \\
\hline
\end{tabular}

NoTE.- OLS regressions, only for alleged offenders released from EM. In cols. 1 and 2, the dependent variable is a dummy that equals one if the offender went back to prison for a new crime in the Province of Buenos Aires after release and zero otherwise. The dependent variable in col. 3 is a dummy that equals one if the offender escaped from the EM system and zero otherwise. Absolute values of robust $t$-statistics are in parentheses. Standard errors are clustered at the judicial district level.

* Significant at 10 percent.

*** Significant at 1 percent.

went to prison, 13 percent $(20 / 153)$, than for the group that spent some time in prison, 20 percent $(46 / 233)$. Instead, there are no registered escapes from prison in our sample.

Note that our recidivism estimates already incorporate the presence of escapees. When an escapee reoffends and is apprehended, he is counted as a recidivist in our sample. Indeed, 18 of the 66 who escaped 
were apprehended again (11 within a year), for a recidivism rate of over 27 percent. This does not count as a crime the act of escaping (otherwise the rate would be 100 percent by construction). ${ }^{34}$ The high recidivism rate of escapees is consistent with the larger coefficient in column 5 in table 6 above, which is simply the basic IV regression in the paper, but simply excluding escapees from EM.

We also studied the hypothesis that those escaping from EM reoffended with harsher crimes. For example, we examined if the seriousness of the crimes committed by escapees had increased relative to their original crime or relative to other groups (such as alleged offenders formerly on EM or formerly in prison) using measures constructed with the minimum penalty established by the penal code for each type of crime. The effects we found were not statistically significant. The same is true when we construct the measure of severity of the crime using other dimensions (e.g., the maximum penalty).

In columns 2 and 3 of table 7, we analyze within the EM sample how the variables that are available to the judge (at least in principle) at the time of the EM allocation decision can predict recidivism and evasion. The results show that previous imprisonment is a significant predictor of both recidivism and evasion within the EM sample. Still, mandating EM for offenders with a previous criminal record could be defended if it were particularly effective in reducing their recidivism. However, we could not find evidence of this (we could not reject the hypothesis of equal effect of EM across the group with prior imprisonment and the rest of the sample; results available on request). Thus, table 7 suggests that a reasonable assignment rule would have excluded offenders with a previous criminal record from the small EM program.

We note that there is no effect of the seriousness of the alleged offense on escape and recidivism. Still we expect a reasonable assignment rule to exclude offenders accused of serious crimes because there is by now some evidence of the negative political repercussions when they escape and reoffend. A good example is the Buenos Aires system: in August 2008, the EM program was criticized (and later on suspended) after one Angel Fernandez escaped EM and killed a family of four (children aged 8 and 10) in an episode known as the "Campana massacre." Fernandez was detained under EM accused of illegal possession of a handgun but had a prior entry into the penal system: in 1987 he had been convicted to 25 years in prison for robbery and rape, followed by triple murder, but had been released after only 15 years. Similar repercussions

\footnotetext{
${ }^{34}$ A different potential problem concerns differential geographic movements of escapees vs. those released from prison. Escapees are theoretically (we do not have evidence on this) less likely to move around (locally or to other countries) as this would make them vulnerable to routine checks by the police.
} 
occurred in the United Kingdom in 2003 and Colombia in 2010 when offenders under EM reoffended. ${ }^{35}$

\section{B. Welfare}

A full derivation of the welfare effects of adopting an EM program is beyond the scope of this paper. However, given that the main parameter we estimate has a central role in such an exercise, we can provide a back-of-the-envelope calculation for the short-run welfare implications of EM. We note, however, that some of the issues we ignore (such as the value to society of having a more humane penal system) are potentially very important. ${ }^{36}$

A simple starting point is $\Delta W$, the change in welfare when an alleged offender is assigned EM instead of prison. This is simply the difference in the expected values of the decision to detain in prison versus EM, $\Delta W=E V_{E M}-E V_{p}$, considered over two periods that differ in length (the first, which is intended supervision, and the second, which follows release). We are ignoring changes in future behavior (beyond the second period), so this measure concerns only short-run welfare effects. Each of these two expected values depends on the fiscal cost and the value of incapacitation during the period of detention and on the expected social benefit following release. In a given period, the latter is simply the cost of the total number of crimes suffered by victims $(V=n v)$ for the fraction that recidivates $(r)$, or $-r_{i} V^{t}$, for $i=$ prison, EM, or escape. This ignores the value of legal work because individuals in our sample have very low wages and employment rates, although the social value of EM might be higher if we allow a labor supply channel whereby alleged offenders on lower future recidivism can be expected to earn higher income. And it assumes, following the evidence presented, that seriousness of the crime does not differ following release from EM versus prison (or escape).

Thus, the expected value of prison is

$$
E V_{p}=-C_{p}-\delta r_{p} V^{2}
$$

\footnotetext{
${ }^{35}$ For the United Kingdom, see Nellis (2006) and "Criminal Removed Tag before Horrific Murder" (Rochdale Observer, March 22, 2005). For Colombia, see "Police Caught a Man Who Violated Detention under Electronic Monitoring” (Elespectador.com, Colombia, March 24, 2010).

${ }^{36}$ Quantifying the benefit to society of having a more civilized penal system is difficult, in part, because it depends on the type of beliefs that prevail in society. For work explaining why people who believe that effort pays (rather than "it's all luck") tend to support harsher punishments, see Di Tella and Dubra (2008).
} 
where the first term is the fiscal cost of prison while imprisonment lasts and the second is the expected benefit to society once the alleged offender is free (discounted by $\delta$ ).

The expected value of EM is calculated in a similar way, adjusting for the lower estimated rate of recidivism and the fact that incapacitation is incomplete because a fraction $e$ of those on EM escape (which to simplify is assumed to happen immediately after being placed on EM):

$$
E V_{E M}=(1-e)\left(-C_{E M}-\delta r_{E M} V^{2}\right)+e\left(-C_{e}-r_{e} V^{1}-\delta r_{e} V^{2}\right)
$$

Note that we are assuming that escaped or released alleged offenders who commit crimes are not arrested and imprisoned during the first period of freedom. ${ }^{37}$ The informal data we obtained suggest that there are no fiscal gains from escape (so that $C_{e}=C_{E M}$ ). Substituting, we find that the benefit from sending an alleged offender to EM instead of prison is

$$
\Delta W=-C_{E M}+C_{p}+\delta V^{2}\left\{r_{p}-\left[(1-e) r_{E M}+e r_{e}\right]\right\}-V^{1} e r_{e},
$$

where the first two terms are the fiscal gain, the third term is the gain in lower future victimization, and the fourth term is the loss in lower current incapacitation. The fiscal gain can be estimated at US $\$ 15,840$. The reason is that the cost of prison per inmate per day in the Province of Buenos Aires during this period can be estimated at 34 dollars per day (calculations based on Centro de Estudios Legales y Sociales [2011] and Gobierno de la Provincia de Buenos Aires [2011]). In contrast, the EM fee paid per bracelet by the provincial government to the private EM provider was approximately $\$ 10$ per day. The average detention length in our sample of EM offenders is 660 days, so this is used as the length of the first period (i.e., the period of intended supervision). This means that the EM program induced a direct fiscal savings of $\$ 15,840(=660$ days $\times$ the cost difference, which is estimated at \$24). These numbers probably underestimate the fiscal gains of EM relative to prison because the latter in Argentina appear to be run on the cheap (e.g., they have a very low staff to inmate ratio relative to federal prisons or US standards). Furthermore,

\footnotetext{
37 This is only mildly consistent with our data: four out of the 20 alleged offenders who went directly to EM and escaped were arrested in the first period. Note that, since our simulations have all the escapees committing a crime and never being caught, our choice to ignore the capture of escapees biases our calculations toward understating the gains from EM.
} 
the EM program is the first (and only) in the country (so that competition between providers could be expected to lower the EM cost), and its size appears to be small (with fixed costs divided by only a small number of bracelets). ${ }^{38}$

The gain in lower future victimization (during the first period following release) is estimated at $\$ 8,056$. The calculation starts by assuming a discount factor of 1 . It then comes to a value for $v$ using an estimate of the dollar cost to the victims of crime in Argentina appearing in Ronconi (2009). Employing victimization surveys and different data sources, he estimates the material losses for robbery at $\$ 508$. This number can be extrapolated for an estimated value of the average crime in our sample of $\$ 340 .{ }^{39}$ Before coming to an estimate for the total number of crimes, we note that we have an empirical estimate for $R_{i}$, the detected recidivism rate (the expression above contains $r_{i}$, the real recidivism rate, with $r_{i}=R_{i} / d$, where $d$ is the "detection" rate). Thus, it is more convenient to use an estimate of the number of crimes per detected criminal. There are several ways to get at this number. One simple approach starts with the number of reported crimes from the official data and then uses the rate of reporting (from victimizations surveys) to reach the total number of crimes per year in the Province of Buenos Aires. For 2008, this is equal to 593,430 new crimes per year (Ministerio de Justicia 2008). Under some simplifying assumptions, this number can be divided by 11,420 , which is the number of new entries into the Buenos Aires penitentiary system, for a total of 51.96 crimes per detected criminal per year. ${ }^{40}$ Extrapolating, during the 2.85 years of release after supervision, the average number of crimes that a released criminal is expected to commit is 148.1. For the difference in detected recidivism rates for the period following intended supervision, $r_{p}-\left[(1-e) r_{E M}+e r_{e}\right]$, we use our key IV estimate, which

\footnotetext{
${ }^{38}$ For the United States, e.g., Aos et al. (2006) estimate the operating cost of imprisonment at $\$ 62$ per day (Pew Charitable Trusts [2010] estimates the daily imprisonment cost in the United States at $\$ 80)$. Instead, they report that an average EM program costs less than $\$ 4$ per offender. Another example is from the state of Washington, where the cost of $\mathrm{EM}$ is $\$ 5.75$, while the cost of a place in jail is about $\$ 61$ per day. For the United Kingdom, the fiscal costs of EM have been on a downward trend and represent about 20 percent of the cost of custody (National Audit Office 2006).

${ }^{39}$ One way to extrapolate beyond robberies is to construct the cost for each crime category using the length of the punishment for each type of crime as a proxy for its severity and then use the observed distribution of crimes after prison in our sample. In this way we come to the expected cost to the victim of one typical crime of $\$ 340$.

${ }^{40}$ The victimization surveys come from Laboratorio de Investigaciones sobre Crimen, Instituciones y Políticas $(2006,2007)$, and the official data are from Ministerio de Justicia (2008). The rate of reporting (typically below 50 percent) is comparable to what has been reported in prior work (the very high reporting rate for auto theft is driven by the formal requests for making insurance claims; see Soares and Naritomi [2010] for a discussion of the determinants of reporting rates).
} 
includes escapees. This is column 3 in table 5, suggesting that the difference in recidivism rates is 16 percentage points. After substitution in the expression for the second term above, we arrive at $\$ 8,056 .{ }^{41}$

Finally, using an assumption of a 100 percent reoffense rate for escapees, we can use these data to calculate the third term (the loss originating in the escapes of alleged offenders during 1.81 years, which is the average duration of detention in our sample, i.e., from lower current incapacitation) at $\$ 5,436$. Thus, the total benefit of sending an alleged offender to EM (instead of prison) over the ensuing 4.66 years is $\$ 18,460$ (or 2.4 times the average GDP per capita in 2009). ${ }^{42}$

This calculation ignores all the police and judicial costs originated by any changes in criminal activity. It also ignores all the public and private pecuniary prevention costs triggered by any variation in crime, as well as the welfare cost of nonpecuniary prevention measures incurred by citizens (for evidence of such adaptation by potential victims across income groups in Buenos Aires during this period, see Di Tella, Galiani, and Schargrodsky [2010]).

A potentially significant omission from this welfare calculation is the possibility that substitution of EM for prison might lead to reduced general deterrence. Although such effects might be minor with a small program like the one implemented in Buenos Aires, they are more likely to appear if the EM program is expanded. ${ }^{43}$ Such reduced deterrence might

\footnotetext{
${ }^{41}$ We assume that arrest rates, conditional on having committed a crime, are similar for the two samples (on the "gambler's fallacy" applied to criminals-whereby apprehended offenders think that they will have better chances of avoiding capture in the future-see Clotfelter and Cook [1993] and Pogarsky and Piquero [2003]). However, if the EM sample has given out more information to the penal system (e.g., an address or family contacts), then the EM sample would be more likely to be rearrested, so the correlation presented in this paper could be an underestimate of the true causal effect. Our sources report that this is not the case because, in their opinion, police investigations are infrequent. Alternatively, we could assume that the prison sample also includes two subgroups (the "nervous," who would have escaped if they could and hence behave like the escapees, and the "calm"). In that case, the gain in lower future victimization would be $\delta V^{2}\left[(1-e)\left(r_{p}-r_{E M}\right)\right]$. Thus, using the IV estimate once escapees are excluded from col. 5 in table 6 and the observed escape rate of 17 percent, we obtain a somewhat larger estimate for the gain in lower future victimization of $\$ 8,776$.

${ }^{42}$ The per capita GDP for Argentina for 2009 was $\$ 7,732$. Source: International Monetary Fund, World Economic Outlook.

${ }^{43}$ Note, however, that some of the best evidence available in the literature concerns specific deterrence (see, e.g., Drago, Galbiati, and Vertova 2009). Lee and McCrary (2009) discuss some of the limitations of earlier work on general deterrence and present evidence consistent with myopic behavior on the part of offenders. Finally, Anderson (2002) reports that the majority of the convicted criminals he interviewed declared to have given little thought to the likely punishment if convicted. Indeed, he finds that 53 percent either did not know the punishment or did not think about it, while 76 percent of the sample lacks information on at least one of the elements judged necessary to have a rational response to punishment.
} 
be balanced if a cheaper, more humane form of punishment invites society to expand the program, resulting in a net increase in the number of people under the supervision of the penal system.

\section{Conclusion}

All societies must decide what to do with those who commit crimes. While a standard approach for centuries has been to incarcerate offenders, an intriguing recent proposal is to use electronic bracelets to monitor offenders from a remote location. As the fiscal burden of the prison population has increased and as the electronic monitoring technology has become cheaper and safer (new devices can include GPS tracking, voice recognition, and transdermal measurement of alcohol and drug consumption), many countries have considered the adoption of these new technologies. Indeed, at least since Jeremy Bentham, who in 1791 proposed the panopticon (a glass prison where inmates could be watched continually by guards who could not be seen; see fig. 3), society has considered how technological and institutional advances could be used to substitute for standard prisons. In this paper we seek to contribute to this debate by providing an estimate of the effect on recidivism of having a person serve time under electronic surveillance instead of prison.

Previous work evaluating the effects of electronic monitoring is inconclusive (see, e.g., Renzema and Mayo-Wilson 2005; Aos et al. 2006). One of the key challenges faced is that, ideally, we would like to compare similar individuals after their release from EM and prison. This is rarely observed in practice because judicial allocation decisions are obviously influenced by the offender's perceived "meanness" and risk of recidivism. This, after all, is part of the reason why countries have a legal system. In this paper we exploit several peculiarities of the legal system in Argentina to study the effect of an EM program, where it is used to substitute for imprisonment of alleged offenders awaiting trial. Given that the majority of alleged offenders never receive a final sentence, the system of preventive imprisonment is a key part of the legal system. This creates a unique opportunity to study the effects of big variation in "incarceration" conditions on serious criminals. Alleged offenders are randomly matched to judges with different propensities to use EM. Such differences occur because standard ideological differences become exaggerated in Argentina when judges have to decide what to do with individuals caught in the act (and hence likely to be guilty) before evaluating all the available evidence in a formal trial (and therefore presumed innocent), and where the alternative to EM is confinement in overcrowded prisons with very poor conditions. In fact, liberal-leaning judges have allocated EM to individuals accused of very serious crimes (including homicide) and with prior records of imprisonment. Moreover, they have 


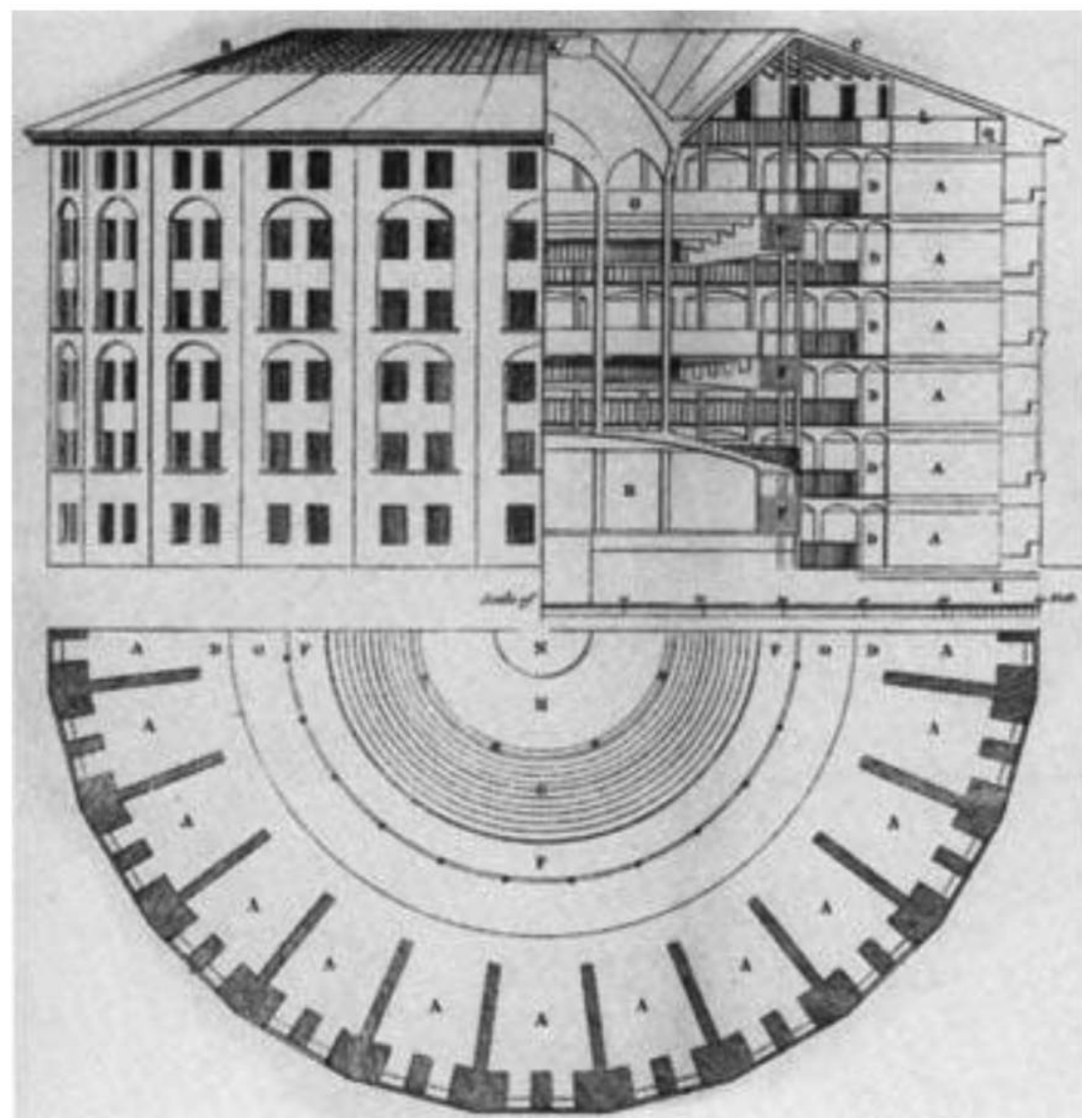

Fig. 3.-Panopticon blueprint, by Jeremy Bentham (1791), drawn by Willey Reveley. A type of prison that allowed prisoners to be monitored at all times (without their being aware of when they are being watched). Bentham himself described the panopticon as "a new mode of obtaining power of mind over mind, in a quantity hitherto without example."

done so with some regularity, while others have never done it since the start of the EM program.

Exploiting random assignment to judges with differing inclinations to assign EM, our main IV estimates suggest that treating alleged offenders with electronic monitoring instead of prison induces a large and significant reduction in recidivism of between 11 and 16 percentage points (which, conservatively, is a reduction of approximately 48 percent of the raw recidivism rate following detention in prison). After including a conservative estimate of the fiscal gains, the gains in lower future recidivism, and the loss from the fact that a fraction of alleged offenders on EM escape, we come to a value of placing an individual on EM instead of prison of $\$ 18,460$ (or 2.4 times the average GDP per capita). 


\section{References}

Aizer, Anna, and Joseph J. Doyle Jr. 2011. "Juvenile Incarceration and Adult Outcomes: Evidence from Randomly-Assigned Judges.” Working paper (February), Dept. Econ., Brown Univ.

Alzua, Maria Laura, Catherine Rodriguez, and Edgar Villa. 2010. "The Quality of Life in Prisons: Do Educational Programs Reduce In-Prison Conflicts?” In The Economics of Crime: Lessons For and From Latin America, edited by Rafael Di Tella, Sebastian Edwards, and Ernesto Schargrodsky, 239-64. Chicago: Univ. Chicago Press (for NBER).

$\rightarrow$ Anderson, David A. 2002. "The Deterrence Hypothesis and Picking Pockets at the Pickpocket's Hanging." American Law and Econ. Rev. 4 (2): 295-313.

$\rightarrow$ Anderson, James M., Jeffrey R. Kling, and Kate Stith. 1999. "Measuring Interjudge Sentencing Disparity: Before and After the Federal Sentencing Guidelines." J. Law and Econ. 42 (April): 271-307.

Aos, Steve, Marna Miller, and Elizabeth Drake. 2006. Evidence-Based Public Policy Options to Reduce Future Prison Construction, Criminal Justice Costs, and Crime Rates. Document 06-10-1201. Olympia: Washington State Inst. Public Policy.

Asociación por los Derechos Civiles. 2006. "Informe ADC sobre el fallo 'Verbitsky, Horacio S/Habeas Corpus.'” Manuscript, Asociacion por los Derechos Civiles, Buenos Aires.

Banister, P. A., F. V. Smith, K. J. Heskin, and N. Bolton. 1973. "Psychological Correlates of Long-Term Imprisonment." British J. Criminology 13 (October): 312-30.

$\rightarrow$ Bayer, Patrick, Randi Hjalmarsson, and David Pozen. 2009. "Building Criminal Capital behind Bars: Peer Effects in Juvenile Corrections.” Q.J.E. 124 (February): 105-47.

$\rightarrow$ Bester, Alan, Christian Randi, and Tim Conley. 2011. "Inference with Dependent Data Using Cluster Covariance Estimators." J. Econometrics 165 (December): 137-51.

Bhati, Avinash, and Alex R. Piquero. 2008. "Estimating the Impact of Incarceration on Subsequent Offending Trajectories: Deterrent, Criminogenic, or Null Effect?” J. Criminal Law and Criminology 98 (September): 207-53.

Borda, Rodrigo, and Luciana Pol. 2007. "Sobrepoblación y hacinamiento carcelario: La instrumentación del fallo 'Verbitsky' y otras estrategias para solucionar el problema.” Working Paper no. 8, Centro de Estudios Legales y Sociales, Buenos Aires.

Bushway, Shawn D., and Raymond Paternoster. 2009. "The Impact of Prison on Crime." In Do Prisons Make Us Safer? The Benefits and Costs of the Prison Boom, edited by Steven Raphael and Michael A. Stoll. New York: Russell Sage Found.

$\rightarrow$ Bushway, Shawn D., and Anne Morrison Piehl. 2007. "The Inextricable Link between Age and Criminal History in Sentencing." Crime and Delinquency 53 (January): 156-83.

Camp, Scott, and Gerry Gaes. 2009. "Unintended Consequences: Experimental Evidence for the Criminogenic Effect of Prison Security Level Placement on Post-release Recidivism.” J. Experimental Criminology 5 (June): 139-62.

Centro de Estudios Legales y Sociales. 2011. Derechos humanos en Argentina. Report. Buenos Aires: CELS.

$\rightarrow$ Chen, Keith, and Jesse Shapiro. 2007. "Do Harsher Prison Conditions Reduce Recidivism? A Discontinuity-Based Approach.” American Law and Econ. Rev. 9 (Spring): 1-29.

$\rightarrow$ Clotfelter, Charles T., and Philip J. Cook. 1993. "The 'Gambler's Fallacy' in Lottery Play.” Management Sci. 39 (December): 1521-25. 
$\rightarrow$ Courtright, K. E., B. L. Berg, and R. J. Mutchnick. 1997. "Effects of House Arrest with Electronic Monitoring on DUI Offenders." J. Offender Rehabilitation 24: $35-51$.

$\rightarrow$ Di Tella, Rafael, and Juan Dubra. 2008. "Crime and Punishment in the 'American Dream.'” J. Public Econ. 92 ( July): 1564-84.

Di Tella, Rafael, Sebastian Galiani, and Ernesto Schargrodsky. 2010. "Crime Inequality and Victim Behavior during a Crime Wave." In The Economics of Crime: Lessons For and From Latin America, edited by Rafael Di Tella, Sebastian Edwards, and Ernesto Schargrodsky, 175-206. Chicago: Univ. Chicago Press (for NBER).

$\rightarrow$ Doyle, Joseph J., Jr. 2008. "Child Protection and Adult Crime: Using Investigator Assignment to Estimate Causal Effects of Foster Care." J.P.E. 116 (4): 746-70.

$\rightarrow$ Drago, Francesco, Roberto Galbiati, and Pietro Vertova. 2009. "The Deterrent Effects of Prison: Evidence from a Natural Experiment." J.P.E. 117 (April): $257-80$.

$\rightarrow$. 2011. "Prison Conditions and Recidivism." American Law and Econ. Rev. 13 (February): 103-30.

$\rightarrow$ Finn, M. A., and S. Muirhead-Steves. 2002. "The Effectiveness of Electronic Monitoring with Violent Male Parolees." Justice Q. 19 (June): 293-312.

$\rightarrow$ Gainey, Randy, Brian Payne, and Mike O'Toole. 2000. "The Relationship between Time in Jail, Time on Electronic Monitoring, and Recidivism: An Event History Analysis of a Jail-Based Program.” Justice Q. 17 (December): 733-52.

Gendreau, Paul, Claire Goggin, and Francis Cullen. 1999. "The Effect of Prison Sentences on Recidivism." User Report 1999-3, Corrections Res., Dept. Solicitor General, Canada, Ottawa.

$\rightarrow$ Glaeser, Edward L., Bruce Sacerdote, and José A. Scheinkman. 1996. "Crime and Social Interactions." Q.J.E. 111 (2): 507-48.

Gobierno de la Provincia de Buenos Aires Argentina. 2011. "Ejecución presupuestaria al 31 de diciembre de 2010.” http://www.cgp.gba.gov.ar/Presupuestaria /Ejecucion.aspx.

Gomme, I. M. 1995. "From Big House to Big Brother: Confinement in the Future." In The Canadian Criminal Justice System, edited by N. Larsen, 489-516. Toronto: Canadian Scholars' Press.

$\rightarrow$ Green, Donald P., and Daniel Winik. 2010. "Using Random Judge Assignments to Estimate the Effects of Incarceration and Probation on Recidivism among Drug Offenders." Criminology 48 (May): 357-87.

$\rightarrow$ Hansen, Kristine. 2003. "Education and the Crime-Age Profile." British J. Criminology 43 (Winter): 141-68.

Helland, Eric, and Alexander Tabarrok. 2007. "Does Three Strikes Deter? A Nonparametric Estimation." J. Human Resources 42 (February): 309-30.

Isla, Alejandro, and Daniel Miguez. 2003. Heridas urbanas: Violencia delictiva y transformaciones sociales en los noventa. Buenos Aires: Editorial de las Ciencias.

$\rightarrow$ Katz, Lawrence, Stephen D. Levitt, and Ellen Shustorovich. 2003. "Prison Conditions, Capital Punishment, and Deterrence." American Law and Econ. Rev. 5 (August): 318-43.

Kling, Jeffrey R. 2006. "Incarceration Length, Employment, and Earnings." A.E.R. 96 (June): 863-76.

Kuziemko, Ilyana. 2013. "How Should Inmates Be Released from Prison? An Assessment of Parole versus Fixed Sentence Regimes." Q.J.E., forthcoming.

Laboratorio de Investigaciones sobre Crimen, Instituciones y Políticas. 2006. Encuesta larga de victimización. Report. Buenos Aires: Univ. Torcuato di Tella. . 2007. Encuesta larga de victimización. Report. Buenos Aires: Univ. Torcuato di Tella. 
Langan, Patrick A., and David J. Levin. 2002. "Recidivism of Prisoners Released in 1994.” Special Report NCJ 193427 (June), Bur. Justice Statis., Off. Justice Programs, US Dept. Justice, Washington, DC.

$\rightarrow$ La Porta, Rafael, Florencio Lopez-di-Silanes, and Andrei Shleifer. 2008. "The Economic Consequences of Legal Origin.” J. Econ. Literature 46 (June): 285332.

Lee, David, and Justin McCrary. 2009. "The Deterrence Effect of Prison: Dynamic Theory and Evidence." Working paper, Law School, Univ. California, Berkeley.

Lerman, Amy. 2009. "The People Prisons Make: Effects of Incarceration on Criminal Psychology." In Do Prisons Make Us Safer? The Benefits and Costs of the Prison Boom, edited by Steven Raphael and Michael A. Stoll. New York: Russell Sage Found.

Marchisio, Adrian. 2004. La duracion del proceso penal en la República Argentina. Montevideo: Konrad-Adenauer-Stiftung A. C.

$\rightarrow$ Marklund, Fredrik, and Stina Holmberg. 2009. "Effects of Early Release from Prison Using Electronic Tagging in Sweden." J. Experimental Criminology 5 (March): 41-61.

Ministerio de Justicia. Seguridad y Derechos Humanos de la República Argentina. 2008. Sistema nacional de información criminal. Report. Buenos Aires: Ministerio de Justicia.

Morris, Norval, and Michael Tonry. 1990. Between Prison and Probation: Intermediate Punishments and a Rational Sentencing System. New York: Oxford Univ. Press.

Nagin, Daniel S. 1998. "Criminal Deterrence: Research at the Outset of the Twenty-First Century." In Crime and Justice: A Review of Research, vol. 23, edited by Michael Tonry. Chicago: Univ. Chicago Press.

Nagin, Daniel S., Francis Cullen, and Cheryl Jonson. 2009. "Imprisonment and Reoffending." In Crime and Justice: A Review of Research, vol. 38, edited by Michael Tonry, 115-200. Chicago: Univ. Chicago Press.

National Audit Office. 2006. The Electronic Monitoring of Adult Offenders. Report. London: Nat. Audit Office.

$\rightarrow$ Needels, Karen E. 1996. "Go Directly to Jail and Do Not Collect? A Long-Term Study of Recidivism, Employment, and Earnings Patterns among Prison Releasees." J. Res. Crime and Delinquency 33 (November): 471-96.

Nellis, Mike. 2006. "The Limitations of Electronic Monitoring: Reflections on the Tagging of Peter Williams." Prison Service J. 164 (March): 3-12.

$\rightarrow$ Payne, A. Abigail. 1997. "Does Inter-judge Disparity Really Matter? An Analysis of the Effects of Sentencing Reforms in Three Federal District Courts." Internat. Rev. Law and Econ. 17 (September): 337-66.

$\rightarrow$ Payne, B. K., and R. R. Gainey. 1998. "A Qualitative Assessment of the Pains Experienced on Electronic Monitoring." Internat. J. Offender Therapy and Comparative Criminology 42 (June): 149-63.

Petersilia, Joan. 1987. Expanding Options for Criminal Sentencing. Santa Monica, CA: Rand Corp.

$\rightarrow$ Petersilia, Joan, and Susan Turner. 1990. "Comparing Intensive and Regular Supervision for High-Risk Probationers: Early Results from an Experiment in California." Crime and Delinquency 36 (January): 87-111.

Pew Charitable Trusts. 2010. "Collateral Costs: Incarceration's Effect on Economic Mobility." Report, Pew Charitable Trusts, Philadelphia.

$\rightarrow$ Piquero, Alex R., and Greg Pogarsky. 2002. "Beyond Stafford and Warr's Reconceptualization of Deterrence: Personal and Vicarious Experiences, Impulsivity, and Offending Behavior." J. Res. Crime and Delinquency 39 (May): $153-86$. 
$\rightarrow$ Pogarsky, Greg, and Alex R. Piquero. 2003. "Can Punishment Encourage Offending? Investigating the 'Resetting' Effect." J. Res. Crime and Delinquency 40 (February): 95-120.

$\rightarrow$ Renzema, Marc, and Evan Mayo-Wilson. 2005. "Can Electronic Monitoring Reduce Crime for Moderate to High-Risk Offenders?” J. Experimental Criminology 1 (Summer): 215-37.

Ronconi, Lucas. 2009. "Los costos de la delincuencia en Argentina: Estimación en base a encuestas de victimización." Manuscript, LICIP, Univ. Torcuato Di Tella.

Schmidt, Annesley, and Christine E. Curtis. 1987. "Electronic Monitoring." In Intermediate Punishments: Intensive Supervision, Home Confinement and Electronic Supervision, edited by Belinda McCarthy. Monsey, NY: Willow Tree Press.

Schonteich, Martin. 2008. "The Scale and Consequences of Pretrial Detention around the World." Open Society Justice Initiative (Spring): 11-44.

$\rightarrow$ Schwartz, Richard D., and Jerome Skolnick. 1962. "Two Studies of Legal Stigma." Soc. Problems 10 (October): 133-38.

$\rightarrow$ Schwitzgebel, Ralph K. 1969. "Issues in the Use of an Electronic Rehabilitation System with Chronic Recidivists." Law and Society Rev. 3:597-615.

$\rightarrow$ Sherman, Lawrence W., and Richard A. Berk. 1984. "The Specific Deterrent Effects of Arrest for Domestic Assault.” American Sociological Rev. 49 (April): 261-72.

$\rightarrow$ Smith, Douglas A., and Patrick R. Gartin. 1989. "Specifying Specific Deterrence: The Influence of Arrest on Future Criminal Activity." American Sociological Rev. 54 (February): 94-106.

Soares, Rodrigo, and Joana Naritomi. 2010. "Understanding High Crime Rates in Latin America: The Role of Social and Policy Factors." In The Economics of Crime: Lessons For and From Latin America, edited by Rafael Di Tella, Ernesto Schargrodsky, and Sebastian Edwards. Chicago: Univ. Chicago Press (for NBER).

Song, L., and R. Lieb. 1993. "Recidivism: The Effect of Incarceration and Length of Time Served.” Manuscript, Inst. Public Policy, Washington State Univ.

$\rightarrow$ Stafford, Mark C., and Mark Warr. 1993. "A Reconceptualization of General and Specific Deterrence." J. Res. Crime and Delinquency 30 (May): 123-35.

Tonry, Michael. 1998. "Intermediate Sanctions." In The Handbook of Crime and Punishment, edited by Michael Tonry. New York: Oxford Univ. Press.

Unidos por la Justicia. 2009. "Informe: Analisis comparativo servicio penitenciario federal-servicio penitenciario bonaerense." Manuscript, Unidos por la Justicia, Buenos Aires.

Villettaz, P., M. Killias, and I. Zoder. 2006. "The Effects of Custodial vs. Noncustodial Sentences on Re-offending: A Systematic Review of the State of the Knowledge." Report to the Swiss National Science Foundation and the Campbell Collaboration Crime and Justice Group, Inst. Criminology and Criminal Law, Univ. Lausanne.

$\rightarrow$ Waldfogel, Joel. 1991. "Aggregate Inter-judge Disparity in Sentencing: Evidence from Three Districts.” Fed. Sentencing Reporter 4:151-54.

Wooldridge, Jeffrey. 2002. Econometric Analysis of Cross Section and Panel Data. 2 vols. Cambridge, MA: MIT Press. 